\title{
Using Raw and Thermally Modified Fibrous Clay Minerals as Low Concentration NH4+-N Adsorbents
}

\section{Christina Vasiliki Lazaratou ( $\square$ lachrist93@yahoo.gr)}

University of Patras: Panepistemio Patron https://orcid.org/0000-0001-8447-9124

Irene E. Triantaphyllidou

University of Patras: Panepistemio Patron

loannis Pantelidis

University of Patras: Panepistemio Patron

Dimitris A. Chalkias

University of the Peloponnese: Panepistemio Peloponnesou

George Kakogiannis

Geohellas S.A.

Dimitrios V. Vayenas

University of Patras: Panepistemio Patron

Dimitrios Papoulis

University of Patras: Panepistemio Patron

\section{Research Article}

Keywords: palygorskite, sepiolite, thermal treatment, $\mathrm{NH} 4+-\mathrm{N}$, water treatment, adsorption, ion exchange

Posted Date: July 12th, 2021

DOI: https://doi.org/10.21203/rs.3.rs-653532/v1

License: (c) (i) This work is licensed under a Creative Commons Attribution 4.0 International License.

Read Full License

Version of Record: A version of this preprint was published at Environmental Science and Pollution Research on October 21st, 2021. See the published version at https://doi.org/10.1007/s11356-02117107-z. 
2 Christina V. Lazaratou ${ }^{1 *}$, Irene E. Triantaphyllidou ${ }^{2}$, Ioannis Pantelidis ${ }^{1}$, Dimitris A. Chalkias ${ }^{3}$, George 3 Kakogiannis ${ }^{4}$, Dimitrios V. Vayenas ${ }^{2,5}$, Dimitrios Papoulis ${ }^{1}$

1*Department of Geology, University of Patras, GR-26504 Patras, Greece, lachristie93@gmail.com

${ }^{2}$ Department of Chemical Engineering, University of Patras, GR-26504 Patras, Greece

${ }^{3}$ Nanotechnology \& Advanced Materials Laboratory, Department of Electrical and Computer Engineering, University of Peloponnese, GR-26334 Patras, Greece

${ }^{4}$ Geohellas S.A., 8A Pentelis Str., GR-175 64 Athens, Greece

45 Institute of Chemical Engineering Sciences, Foundation for Research and Technology, PO Box 1414, GR-26504, 5 Patras, Greece

\section{Abstract}

Raw and modified fibrous clay minerals palygorskite (Pal) and sepiolite (Sep) were tested for their ability to remove ammonium from ammonium polluted water. Palygorskite and sepiolite underwent thermal treatment at $400^{\circ} \mathrm{C}(\mathrm{T}-\mathrm{Pal}$ and T-Sep respectively). Raw and thermally treated samples were characterized using XRD, SEM, BET, FT-IR, TGA, zeta potential and XRF. The techniques verified the effect of thermal treatment on samples structures and the enhancement of negative charge. Both raw and thermally-activated materials applied in batch kinetic experiments, and found to be efficient adsorbents in their raw forms, since Pal and Sep achieved 60 and $80 \% \mathrm{NH}_{4}{ }^{+}-\mathrm{N}$ removal respectively within 20 min of contact for initial $\mathrm{NH}_{4}{ }^{+}-\mathrm{N}$ concentration of $4 \mathrm{mg} / \mathrm{L}$. Similar removal rates were gained for other concentrations representative of contaminated aquifers that were examined, ranging from $1 \mathrm{mg} / \mathrm{L}$ to $8 \mathrm{mg} / \mathrm{L}$. Results for the modified TPal and T-Sep minerals showed up to $20 \%$ higher removal rate. Saturation tests indicated the positive effect of thermal treatment on the minerals since T-Pal and T-Sep removal efficiency reached $85 \%$ and remained stable for 24 h. However, competitive ions in real water samples can influence the $\mathrm{NH}_{4}{ }^{+}-\mathrm{N}$ removal efficiency of the examined samples. In all cases, the Freundlich isotherm and pseudo-second kinetic models showed better fitted all examined samples thus indicating heterogeneous chemisorption.

Keywords: palygorskite, sepiolite, thermal treatment, $\mathrm{NH}_{4}{ }^{+}-\mathrm{N}$, water treatment, adsorption, ion exchange

\section{Introduction}

Ammonium $\left(\mathrm{NH}_{4}^{+}\right)$is an inorganic pollutant mostly found in wastewater discharges, landfill leachates, industrial sewage and agricultural areas (Böhlke et al. 2006). It is commonly found in aquifers contaminated from one of the abovementioned pollution sources because it is a highly mobile contaminant (Böhlke et al. 2006). Ammonium can be extremely toxic since it can be transformed into $\mathrm{NO}_{2}{ }^{-}$or $\mathrm{NO}_{3}{ }^{-}$via the nitrification process under oxidant conditions and 
lead to eutrophication in aquatic ecosystems (Rožić 2000). Moreover, when ingested in quantities exceeding $100 \mathrm{mg} / \mathrm{kg}$ of body weight per day, it can cause the formation of ammonium salts, such as ammonium chloride, that are toxic to human health (WHO 2003). The European Union has set the permitted limit of $\mathrm{NH}_{4}{ }^{+}$in groundwater as $0.5 \mathrm{mg} / \mathrm{L}$ (WHO 2017). In general, the $\mathrm{NH}_{4}{ }^{+}-\mathrm{N}$ concentration in aquifers is $<0.2 \mathrm{mg} / \mathrm{L}$, however when anaerobic conditions dominate, concentrations of 1-5 mg/L can be reached (Voudouris et al. 2013; Rusydi et al. 2020) .

A variety of methods has been applied for $\mathrm{NH}_{4}{ }^{+}$removal from water, such as biological treatment (Yang et al. 2019; Zeng et al. 2020), air stripping (Gui and Li 2019) and physicochemical techniques, like sorption mechanism (Hou et al. 2016; $\mathrm{Vu}$ et al. 2017). Zeolite has been widely used for $\mathrm{NH}_{4}{ }^{+}$retention since it is a low-cost, widely available and environmental-friendly material (Fu et al. 2020). Nevertheless, limited research has investigated the efficiency of clay minerals for $\mathrm{NH}_{4}{ }^{+}$removal (Alshameri et al. 2018) despite them being as abundant and low-cost as other industrial minerals.

Clay minerals consist of silicon-oxygen tetrahedral and aluminum- oxygen octahedral sheets which are responsible for their permanent negative charge. The charge is balanced with cationic interlayer counterions which are exchangeable with other organic or inorganic cations. These counterions are responsible for the minerals high cation exchange capacity (CEC) (Brigatti et al. 2013). The high CEC and the permanent negative charge that clay minerals present, render them promising adsorbents for various cationic pollutants (Lazaratou et al. 2020a).

Palygorskite (Pal) and sepiolite (Sep) are the only clay minerals classified as belonging to the fibrous group with a ribbon-like structure (Galán 1996). Both Pal and Sep are 2:1 clay minerals and their special structural characteristics include high porosity, high specific surface area (SSA) and numerous inner nano-tunnels. Despite the fact that the fibrous clay minerals present relatively low CEC (Galán 1996), the aforementioned properties ensure both these clay minerals have high adsorption capacities. Moreover, Pal and Sep deposits exist worldwide, most of which are exploited for a variety of industrial applications (Murray et al. 2011). Considering that the fibrous clay minerals are used in industry quite commonly as other clays such as bentonite, their study in environmental applications as adsorbents is crucial, since could be an alternative and cost-effective choice, especially for the areas that the relative deposits exist (Kastritis et al. 2003; Yeniyol 2012).

51 Thermal treatment, or calcination, has been applied to Pal and Sep to improve their adsorption capacities since at temperatures above $100^{\circ} \mathrm{C}$ the water in their intercrystalline tunnels is removed causing modifications in their pore structure and SSA (Chen et al. 2011b). At temperatures of $350-1000^{\circ} \mathrm{C}$ dehydroxylation takes place, which may reveal negatively charged sites and result in additional protonated surfaces (Zuo et al. 2017; Lazaratou et al. 2020b). This 
physical modification outweighs other modification techniques in terms of operational simplicity and cost, as only the cost entailed is that of energy demand which depends on calcination temperature and time.

57 This study evaluates the effectiveness of raw and thermally-treated palygorskite and sepiolite minerals as cost-effective $58 \mathrm{NH}_{4}{ }^{+}-\mathrm{N}$ adsorbents. Experiments focused on the removal of low concentrations of $\mathrm{NH}_{4}{ }^{+}-\mathrm{N}$ that are commonly found in contaminated aquifers as few studies have concentrated on $\mathrm{NH}_{4}{ }^{+}-\mathrm{N}$ removal from groundwater. Moreover, thermal treatment has not been previously applied to fibrous clay minerals intended for ammonium removal. To determine the optimum operational conditions, all samples were mineralogically characterized with XRD, SEM, BET, $\mathrm{N}_{2}$ sorption desorption isotherms, FT-IR, TGA, zeta potential and XRF methods, while batch kinetic experiments were conducted with varying adsorbent dosages, initial $\mathrm{NH}_{4}{ }^{+}-\mathrm{N}$ concentrations, contact time and $\mathrm{pH}$ values. Saturation tests were carried out to examine the potential reusability of the adsorbents. Isotherms and kinetic models were applied to determine the nature of the adsorption process.

\section{Materials and Methods}

\subsection{Samples preparation and thermal treatment}

The Pal sample was supplied from Geohellas S.A. (Ventzia basin Grevena, Greece) while Sep was collected from Solomos village (Korinthos, Greece). The raw samples were washed with distilled water and dried at $40^{\circ} \mathrm{C}$ for $48 \mathrm{~h}$ then sieved until powder diffraction was obtained $(<50 \mu \mathrm{m})$. For the thermal treatment, $20 \mathrm{~g}$ of each powdered sample was treated at $400^{\circ} \mathrm{C}$ in a controlled muffled oven for $2 \mathrm{~h}$ and then cooled at room temperature in a desiccator. The temperature of $400^{\circ} \mathrm{C}$ was selected since it is the minimum where both coordinated water loss and dehydroxylation take place within the samples, thus, ensuring effective structural changes and cost effectiveness (Perraki and Orfanoudaki 2008; Chen et al. 2011b).

\subsection{Characterization methods}

Before any characterization method, the raw and thermally treated Pal and Sep samples were dried at $50^{\circ} \mathrm{C}$ for $24 \mathrm{~h}$ to maintain the representative conditions applied to the samples before adsorption batch tests. X-ray diffraction (XRD) patterns were obtained for the samples in a $2 \theta$ range of $2^{\circ}$ to $60^{\circ}$ and at a scanning rate of $2^{\circ} / \mathrm{min}$, using XRD Bruker D8 advance diffractometer, with $\mathrm{Ni}$-filtered $\mathrm{CuK}_{\alpha}$ radiation $(\lambda=1.5418 \AA$ ). For the semi-quantitative analysis of the clay minerals composition, the Area method was used according to Bridley and Brown (1980). Their typical morphological characteristics were verified with scanning electron microscopy (SEM), using a SEM LEO SUPRA 35VP. The $\mathrm{N}_{2}$ adsorption-desorption isothermal tests were carried out at $77 \mathrm{~K}$ on the samples that were previously degassed at $100^{\circ} \mathrm{C}$ for 
$833 \mathrm{~h}$, using Micromeritics Tristar 3000 analyzer which is equipped with a SmartPrep degasser. From these isotherms, the 84 Brunauner-Emmet-Teller (BET) surface area, pore size and pore distribution were determined for all the samples.

85 Fourier-transform infrared spectroscopy (FTIR) spectra were obtained using FT-IR spectrophotometer Spectrum RXI (Perkin Elmer) at room temperature. The samples were prepared by mixing $0.1 \mathrm{mg}$ of Pal, Sep, T-Pal and T-Sep with

$87 \mathrm{KBr}$, and then were pressed till pellets were formed. The spectra were collected over 12 scans in the wavenumbers range from $400 \mathrm{~cm}^{-1}$ to $4000 \mathrm{~cm}^{-1}$, and were analyzed using Spectrum v5.3.1 software. Thermogravimetric analysis (TGA) was conducted on a Perkin Elmer Simultaneous Thermal Analyzer STA6000 controlled by Pyris Manager Software, using nitrogen as a purging gas. For each run, a weighted amount of sample powder $(\cong 10 \mathrm{mg})$ was loaded on a ceramic pan and heated from $40^{\circ} \mathrm{C}$ to $600^{\circ} \mathrm{C}$, at a heating rate of $10^{\circ} \mathrm{C} / \mathrm{min}$. Before each measurement, all samples were subjected to isothermal heating at $40^{\circ} \mathrm{C}$ for $30 \mathrm{~min}$ to eliminate the adsorbed water on their surface from their exposure to ambient atmosphere, simulating the drying process carried out before each case of their characterization. The X-Ray florescence (XRF) measurements of the major $\left(\mathrm{SiO}_{2}, \mathrm{Al}_{2} \mathrm{O}_{3}, \mathrm{CaO}, \mathrm{MgO}, \mathrm{MnO}, \mathrm{Fe}_{2} \mathrm{O}_{3}, \mathrm{~K}_{2} \mathrm{O}, \mathrm{Na}_{2} \mathrm{O}, \mathrm{P}_{2} \mathrm{O}_{5}, \mathrm{TiO}_{2}\right.$ ) elements were performed. An amount of $1.8 \mathrm{~g}$ of dried ground sample was mixed with $0.2 \mathrm{~g}$ of wax (acting as a binder) and was pressed on a base of boric acid to a circular powder pellet of $3.2 \mathrm{~cm}$ in diameter. Analyses were performed with a RIGAKU ZSX PRIMUS II spectrometer, which was equipped with a $\mathrm{Rh}$-anode running at $4 \mathrm{~kW}$, for major and trace elements analysis.

The spectrometer was equipped with the diffracting crystals: LIF (200), LIF (220), PET, Ge, RX-25, RX-61, RX-40 and RX-75. The samples zeta potential was determined by a Zetasizer, Nano ZS (Malvern, UK). For the measurements, dilute suspensions of various $\mathrm{pH}$ values (4-11) and standard ionic strength $\left(0.01 \mathrm{M} \mathrm{KNO} \mathrm{KN}_{3}\right)$ were used. The zeta potential was reported as the mean of two measurements, and each measurement was the sum of 14 correlograms and fitting procedures.

\subsection{Batch kinetic experiments}

A series of batch kinetic experiments was conducted for raw Pal, raw Sep, T-Pal, and T-Sep under various adsorbent dosages $\left(0.4,0.8,1.6\right.$ and $4.0 \mathrm{~g}$ in $200 \mathrm{ml}$ solution), initial $\mathrm{NH}_{4}{ }^{+}-\mathrm{N}$ concentrations $(1,2,4,6$, and $8 \mathrm{mg} / \mathrm{L})$ and $\mathrm{pH}$ values $\left(2,3,5,7,9\right.$ and 11). Solution $\mathrm{pH}$ was adjusted using either $\mathrm{H}_{2} \mathrm{SO}_{4}$ or $\mathrm{NaOH}$ for acidic and basic values, respectively. The standard $\mathrm{NH}_{4}{ }^{+}-\mathrm{N}$ solutions were prepared by dilution of $\mathrm{NH}_{4} \mathrm{Cl}$ in deionized water, at standard ionic strength $I=0.1$ $\mathrm{M}$ using $\mathrm{KClO}_{4}$. The adsorption process was carried out using the jar tester VELP Scientifica JLT6 at $210 \mathrm{rpm}$. Samples were collected at different time intervals $(2.5,5,10,15,20,30$ and $40 \mathrm{~min})$ and were centrifuged at $5500 \mathrm{rpm}$ for $3 \mathrm{~min}$. The supernatant was filtrated through Whatman filters $(0.45 \mu \mathrm{m})$ to remove the finest suspended particles. The final removal efficiency was determined according to Equation 1: 
$112 R \%=\frac{\left(C_{o}-C_{e}\right)}{C_{0}} \cdot 100$

113 where $C_{0}$ is the initial $\mathrm{NH}_{4}{ }^{+}-\mathrm{N}$ concentration, and $C_{e}$ is the $\mathrm{NH}_{4}{ }^{+}-\mathrm{N}$ concentration after adsorption in equilibrium.

\section{$114 \quad$ 2.4 Saturation test}

115 For the saturation test, the adsorbents were left in contact with $4 \mathrm{mg} / \mathrm{L} \mathrm{NH}_{4}{ }^{+}-\mathrm{N}$ for 24 h under constant stirring. Samples 116 were then treated as described above and $\mathrm{NH}_{4}{ }^{+}-\mathrm{N}$ was measured according to the analytical methods described in Section 117 2.6. The procedure was repeated until each adsorbent was saturated and no further $\mathrm{NH}_{4}{ }^{+}-\mathrm{N}$ could be adsorbed.

\subsection{Batch study on a real water system}

119 In these batch series the optimal adsorbents' dosage was applied in $200 \mathrm{ml}$ of University of Patras tap water. $\mathrm{NH}_{4}{ }^{+}-\mathrm{N}$ 120 concentration was artificially added to the real water sample in accordance with the other batch tests. Samples were then treated as described above and $\mathrm{NH}_{4}{ }^{+}-\mathrm{N}$ was measured according to the analytical methods described in Section 2.6. The

122 physicochemical characteristics of the water sample are described in Table 1.

\begin{tabular}{|c|c|}
\hline Physicochemical Characteristics & Tap Water Sample \\
\hline $\mathrm{pH}$ & 7.3 \\
\hline Electrical Conductivity $(\mu \mathrm{S} / \mathrm{cm})$ & 880 \\
\hline $\begin{array}{c}\text { Total Hardness } \\
(\mathrm{mg} / \mathrm{L}, \mathrm{CaCO})\end{array}$ & 487 \\
\hline $\mathrm{Ca}^{+2}(\mathrm{mg} / \mathrm{L})$ & 159 \\
\hline $\mathrm{Mg}^{+2}(\mathrm{mg} / \mathrm{L})$ & 22 \\
\hline $\mathrm{Na}^{+}(\mathrm{mg} / \mathrm{L})$ & 26 \\
\hline
\end{tabular}

\subsection{Analytical methods}

$131 \mathrm{NH}_{4}{ }^{+}-\mathrm{N}$ concentrations were measured using a UV-VIS spectrophotometer Hach Lange DR 5000 at $625 \mathrm{~nm}$ according to 132 the modified salicylate method (Verdouw et al. 1978). Each sample was reacted with 6\% sodium hypochlorite solution 133 and salicylate/catalyst solution (sodium salicylate $10 \%$, sodium nitroferricyanide $0.04 \%$ and sodium hydroxide $0.5 \%$ ). $134 \mathrm{NH}_{4}{ }^{+}-\mathrm{N}$ concentrations were measured after 10 min color development. All experiments were conducted in duplicate. 
136 Data from the adsorption experiments were fitted in Langmuir and Freundlich isotherms to determine adsorbent surface sites - adsorbate ions relationship (Aydın Temel and Kuleyin 2016) according to the following equations:

$q_{e}=\frac{\left(C_{0}-C_{e}\right) V}{m}$

139 where $q_{e}$ is the amount of exchanged ions $(\mathrm{mg} / \mathrm{g}), C_{0}$ and $C_{e}$ are the initial and equilibrium $\mathrm{NH}_{4}{ }^{+}-\mathrm{N}$ concentrations in 140 solution ( $\mathrm{mg} / \mathrm{L}$ ), respectively, $V$ is the solution volume $(\mathrm{L}), \mathrm{m}$ is the adsorbent weight $(\mathrm{g})$,

$141 \quad \frac{c_{e}}{q_{e}}=\frac{1}{q_{\max } K_{L}}+\left(\frac{1}{q_{\max }}\right) c_{e}$

142 where constant $K_{L}$ is the $C_{e} / q_{e}$ ratio vs. $C_{e}$ variation, where $q_{\max }$ is used, expressing the $\mathrm{NH}_{4}{ }^{+}-\mathrm{N}$ maximum uptake. The fit 143 to the Langmuir isotherm (Equation 3) indicates the nature of the monolayer adsorption (Aydin Temel and Kuleyin 144 2016)

145 The Freundlich isotherm expresses heterogeneous adsorption surfaces with unequal active sites and energies of 146 adsorption (Yagub et al. 2014) and can be expressed as:

$147 \quad \ln q_{e}=\ln K_{F}+\frac{1}{n} \ln c_{e}$

148 where $q_{e}$ is the amount of exchanged ions $(\mathrm{mg} / \mathrm{g}), C_{e}$ is the equilibrium $\mathrm{NH}_{4}{ }^{+}-\mathrm{N}$ concentrations in solution $(\mathrm{mg} / \mathrm{L}), K_{F}$ is 149 the adsorbent capacity, and $n$ is the Freundlich constant. When $1 / n$ is $0<1 / n<1$ adsorption is considered favorable, 150 when $1 / n=1$ adsorption is linear and irreversible, and when $1 / n>1$ adsorption is a chemical process and unfavorable. 151 The value of $1 / n<1$ indicates the adsorption process is physical (Aydın Temel and Kuleyin 2016).

\section{$152 \quad 2.8$. Adsorption kinetic models}

153 The adsorption rate of $\mathrm{NH}_{4}{ }^{+}-\mathrm{N}$ on Pal, Sep, T-Pal and T-Sep can be estimated via kinetic models application, as well as 154 the optimal adsorption mechanism and adsorbent surficial characteristics can be approached (Karri et al. 2017). 155 Specifically, the pseudo-first order kinetic model focused on pollutant adsorption mechanisms and the pseudo-second 156 order kinetic model was applied to predict the chemisorption of $\mathrm{NH}_{4}{ }^{+}-\mathrm{N}$ onto the tested adsorbents. The linearized forms 157 of the kinetic models are expressed by Equations 5 and 6, respectively. 
$159 \frac{t}{q_{t}}=\frac{1}{k_{2} q_{e}^{2}}+\frac{1}{q_{e}} t$

160 where $q_{t}$ is the amount of adsorbed pollutant at time $t(\mathrm{mg} / \mathrm{g})$, and $k_{1}(1 / \mathrm{min})$ and $k_{2}(\mathrm{~g} / \mathrm{mg}$ min) are the rate constants of $161 \mathrm{NH}_{4}{ }^{-}-\mathrm{N}$ adsorption for the pseudo- first and second order kinetic models, respectively (Karri et al. 2017). The $k_{l}$ value 162 can be determined from the slope of the linear plot of $\ln \left(q_{e^{-}} q_{t}\right)$ vs $t$, and $k_{2}$ from the intercept of the linear plot of $t / q_{t}$ vs $t$. 163 Although both models indicate the adsorption mechanism through time, neither takes into account the diffusion 164 mechanism that can be expressed according to the Weber-Morris model, otherwise known as the intraparticle diffusion model, in Equation 7.

$q=k_{i d} \sqrt{t}+I$

where $q$ is the adsorbate amount at time $t$ and $k_{i d}$ is the intraparticle diffusion constant $\left(\mathrm{mg} / \mathrm{g} \mathrm{min}^{-1 / 2}\right)$. The $k_{i d}$ parameter can be calculated from the slope of the $q_{t}$ vs $t^{0.5}$ linear plot, while $I$ is the intercept of the vertical axis. If the WeberMorris plot is linear, $I=0$ and intraparticle diffusion is the rate limiting step, but when $I>0$ two steps take place, firstly the film, followed by the intraparticle diffusion as the rate limiting steps (Svilović et al. 2010).

\section{Results and Discussion}

\subsection{Adsorbent characteristics and proposed $\mathrm{NH}_{4}{ }^{+}-\mathrm{N}$ removal mechanism}

\section{$173 \quad$ 3.1.1. XRD}

The XRD pattern of palygorskite sample (Pal) was characterized by Pal reflections at $2 \theta^{\circ}$ values $8.3^{\circ}, 20^{\circ}, 27^{\circ}$ and $34^{\circ}$, rendering palygorskite the dominant mineralogical phase $(96 \%)$ at Pal sample. The $2 \theta^{\circ}$ reflection at $6^{\circ}$ indicated the predicted occurrence of saponite as impurity (4\%), since this mineral coexists with Pal in the Ventzia basin deposit (Fig. 1a). Differences were shown at Pal reflections after thermal treatment (T-Pal) (Fig. 1b), where the first characteristic Pal reflection intensity at $8.3^{\circ}$ was sharply decreased, in contrast to the extended reflection of saponite. Similar results were observed by Yan et al. (2012), who recorded a decreased Pal reflection at $8.3^{\circ}$, while a new reflection at $30^{\circ}$ was formed by dehydration and structural rearrangement. After $\mathrm{NH}_{4}{ }^{+}-\mathrm{N}$ adsorption, both $\mathrm{Pal}\left(\mathrm{Pal} \mathrm{N \textrm {N } _ { 4 }}{ }^{+}-\mathrm{N}\right)$ and $\mathrm{T}-\mathrm{Pal}\left(\mathrm{T}-\mathrm{Pal} \mathrm{NH}{ }^{+}-\mathrm{N}\right)$ samples preserved the same mineral phases that were described above, since the existed main palygorskite reflections and saponite impurity were observed (Fig. 1a,b). However, at $\mathrm{Pal} \mathrm{NH}_{4}{ }^{+}-\mathrm{N}$ and T-Pal $\mathrm{NH}_{4}{ }^{+}-\mathrm{N}$ samples. The reflections attributed to palygorskite are decreased, as well as a slight peak shifting was observed at the basal reflections of $20^{\circ}$ and $35^{\circ}$ (Fig. 1a,b). The intensity change of the reflections highlights the surficial interaction between adsorbent- adsorbate (Papoulis et al. 2019), whereas the peak shifting can be attributed either to the ion exchange that took place or to the 
surficial bonding that may affect the crystallinity. Moreover, even the small presence of saponite may influence the surficial interactions with $\mathrm{NH}_{4}{ }^{+}$, since saponite consists of multiple $\mathrm{OH}^{-}$groups on its surface (Zhou et al. 2019).

At the XRD pattern of the sepiolite sample (Sep) the reflections of all other minerals were absent apart from an impurity of calcite at the reflection at $30^{\circ}$ in content of $2 \%$ (Fig. 1c). The dominant sepiolite's presence was verified by the typical Sep reflections at $7.2^{\circ}, 20^{\circ}$ and $35^{\circ}$, rendering sepiolite the main mineralogical phase (98\%). The impact of thermal treatment (T-Sep) on Sep structure is revealed, since two new reflections appear at $7.3^{\circ}$ and $11.04^{\circ}$ (Fig. 1d) due to the formation of sepiolite anhydrite that occurs at temperatures above $350^{\circ} \mathrm{C}$ (Perraki and Orfanoudaki 2008). After $\mathrm{NH}_{4}{ }^{+}-\mathrm{N}$ adsorption, Sep $\left(\mathrm{Sep} \mathrm{NH}_{4}{ }^{+}-\mathrm{N}\right)$ and T-Sep (T-Sep $\left.\mathrm{NH}_{4}{ }^{+}-\mathrm{N}\right)$ samples presented opposed behavior from $\mathrm{Pal} \mathrm{NH}_{4}{ }^{+}-\mathrm{N}$ and $\mathrm{T}$ Pal $\mathrm{NH}_{4}{ }^{+}-\mathrm{N}$ samples, since there was no shifting occurred, while the main reflection at $7.2^{\circ}$ in both samples was steeply increased (Fig. 1c, d). Potentially the Sep and T-Sep purity led to enhanced interactions of the samples pores with $\mathrm{NH}_{4}{ }^{+}$, contributing to the sharply increased reflections (Marler et al. 1996). This verifies the ammonium interaction with the inside of Sep or T-Sep structure without altering the crystal structure of the samples. Similar behavior was reported in the study of Alshameri et al. (2018) for vermiculite as ammonium adsorbent.

\subsubsection{SEM}

SEM images revealed the morphology of the Pal and Sep samples before and after thermal treatment. The fibrous morphology of Pal and Sep were verified (Figs. 2a, 2c respectively), with fiber lengths ranging from $250 \mathrm{~nm}$ to $1 \mu \mathrm{m}$. The effect of thermal treatment at $400^{\circ} \mathrm{C}$ was significant in both samples (Figs. 2b, d). Specifically, T-Pal fibers (Fig. 2b) were strongly agglomerated and their length decreased after thermal treatment as a result of the total loss of coordinated water molecules (Bu et al. 2011; Xavier et al. 2016). T-Sep also presented similar characteristics (Fig. 2d) with shorter fibers and agglomeration due to the loss of water molecules (Perraki and Orfanoudaki 2008; Miura et al. 2012).

\subsubsection{BET surface area and pore size distribution}

The $\mathrm{N}_{2}$ adsorption-desorption isotherms for raw and thermally-treated clay minerals are presented in Fig. 3. Based on the IUPAC classification, the isotherms were classified as Type $I V$ with $H_{3}$-type hysteresis loop, indicating the dominance of mesoporosity but also the presence of micropores (Sing et al. 1984). The overlap at $P / P_{0}<0.4$ verified the microporosity, while the limited loop at $0.7<P / P_{0}<0.9$ is typical of low degree mesoporosity (Cases 1991; Wang et al. 2016), which may be attributed to aggregates or capillary condensation of typical $H_{3}$-type loop and isotherm Type $I V$, respectively (Sing et al. 1984). After thermal treatment at $400^{\circ} \mathrm{C}$ the loop at $0.6<P / P_{0}<0.9$ steepened. This was especially noticeable 
214 in T-Sep, since Sep is more fragile than palygorskite due to its Mg-rich composition and the size of its structural microchannels (Myriam 1998). Up to $350^{\circ} \mathrm{C}$ the loss of Sep first coordinated water causes reversible inner channels folding, but from $400^{\circ} \mathrm{C}$ the folding is irreversible, with Sep preserving its structure (Myriam 1998).

217 The SSA values, average pore diameters or widths, and the total pore volumes of the Pal, Sep, T-Sep and T-Pal minerals were determined as well (Table 2). The thermally - treated samples showed a $>50 \%$ reduction in SSA as the zeolitic water and part of the coordinated water or magnesium-coordinated water respectively are removed during treatment (Perraki and Orfanoudaki 2008; Chen et al. 2011a). This removal of $\mathrm{Mg}^{+2}$ within the T-Sep structure may caused the reduction in SSA, whereas the increased pore volume could be attributed to this structural rearrangement, as well as the secondary occurrence of microporosity resulted from the dehydration of silanol groups which may also explain the more intense loop observed after calcination (Balci 1999). In contrast, after calcination at temperatures exceeding $400^{\circ} \mathrm{C}$, the pore size of T-Pal reduced due to the collapse of Pal nano tunnels and the condensation of silanol groups (Chen et al. 2011a).

Table 2. Specific Surface Area (SSA), average pore diameter and total pore volume of Pal, Sep, T-Pal and T-Sep.

\begin{tabular}{cccc}
\hline Samples & SSA $\left(\mathbf{m}^{\mathbf{2}} \mathbf{g}\right)$ & Average pore diameter $(\mathbf{n m})$ & Total pore volume $\left(\mathbf{c m}^{\mathbf{3}} / \mathbf{g}\right)$ \\
\hline Pal & 221.0 & 7.2 & 0.40 \\
Sep & 230.0 & 6.2 & 0.24 \\
T-Pal & 101.9 & 7.4 & 0.196 \\
T-Sep & 116.7 & 10.4 & 0.32 \\
\hline
\end{tabular}

\subsubsection{FT-IR}

The FT-IR spectra of raw and thermally modified Pal and Sep before, and after $\mathrm{NH}_{4}{ }^{+}-\mathrm{N}$ adsorption can be observed in Figs. 4 a-d. Pal sample (Fig. 4a) presented typical bands of Si - O stretching, slightly shifted, at $469 \mathrm{~cm}^{-1}, 1024 \mathrm{~cm}^{-1}$, $1170 \mathrm{~cm}-1$ and $1655 \mathrm{~cm}^{-1}$ (Madejová et al. 2017), whereas the band at $1170 \mathrm{~cm}^{-1}$ can be Si-O bond that connects two inverse $\mathrm{SiO}_{4}$ of palygorskite structure, and the $1200 \mathrm{~cm}^{-1}$ band is typical of the ribbon structure (Blanco et al. 1989; Yan et al. 2012). Saponite impurity can be verified based on the band at $650 \mathrm{~cm}^{-1}$ (Lainé et al. 2017). At the range of $3610 \mathrm{~cm}^{-}$

${ }^{1}$ to $\sim 3200 \mathrm{~cm}^{-1}$ characteristic bands of $\mathrm{OH}^{-}$from zeolitic water groups coordinated with structural $\mathrm{Mg}$ are shown (Xavier et al. 2016). The FT-IR data verified XRD results that thermal treatment did not influence the mineralogical phase of palygorskite, since the same bands with the raw sample are maintained (Fig. 4b). Moreover, the vibration of the band at $1170 \mathrm{~cm}^{-1}$ in Fig. 4b is steeply decreased after thermal treatment and a new band at $882 \mathrm{~cm}^{-1}$ appeared; similarly to the observation of Yan et al. (2012) for the analogous band at $1196 \mathrm{~cm}^{-1}$ and at $885 \mathrm{~cm}^{-1}$ respectively. Vibration decrease and 
shifting at $\sim 3400 \mathrm{~cm}^{-1}$ to $\sim 3600 \mathrm{~cm}^{-1}$ that was followed, can be attributed to a partial loss of bound water after the thermal treatment (Fig. 4b). The total loss of water could be achieved at temperature higher than $700^{\circ} \mathrm{C}$ (Xavier et al. 2016). After

$242 \mathrm{NH}_{4}{ }^{+}-\mathrm{N}$ adsorption on Pal (Fig 4a) an intense band at $1380 \mathrm{~cm}^{-1}$ can be attributed to the newly formed $\mathrm{N}-\mathrm{H}$ bond, rendering the ammonium removal on Pal by chemisorption (He et al. 2016).

244 The FT-IR spectra of Sep sample (Fig. 4c) presented bands at $463 \mathrm{~cm}^{-1}, 683 \mathrm{~cm}^{-1}, 830 \mathrm{~cm}^{-1}, 889 \mathrm{~cm}^{-1}$ and $1020 \mathrm{~cm}^{-1}$ that are referred to Si-O-Si bonds, whereas the bands at $1659 \mathrm{~cm}^{-1}$ and $3419 \mathrm{~cm}^{-1}$ can be attributed to zeolitic water molecules. In addition, the bands at $441 \mathrm{~cm}^{-1}$ and $3568 \mathrm{~cm}^{-1}$ are representative of Si-O-Mg and surficial $\mathrm{Mg}-\mathrm{OH}$ bonds of sepiolite respectively (Perraki and Orfanoudaki 2008). After thermal treatment at $400^{\circ} \mathrm{C}$ the $\mathrm{Mg}$ - bonds bands are steeply decreased (Fig. 4d), inducing significant shifting at Si-O-Si band from $463 \mathrm{~cm}^{-1}$ to $474 \mathrm{~cm}^{-1}$. These results come in agreement with the BET analysis where Sep structural rearrangement and $\mathrm{Mg}$ - removal were referred. $\mathrm{After}^{\mathrm{NH}_{4}{ }^{+} \mathrm{N}}$ adsorption, a slight shifting was observed at the band areas $1260-1390 \mathrm{~cm}^{-1}$ and $616-730 \mathrm{~cm}^{-1}$, whereas band differences occurred at the area of $1380-1390 \mathrm{~cm}^{-1}$. However, there is not an intense new band; typical of $\mathrm{N}-\mathrm{H}$ bonding, because the bands of the sepiolite mineral may overlap these bands. The slight occurred band shifting could be attributed to interactions taking place on the surface, however, are not as intense as it was observed at Pal and T-Pal samples.

\subsubsection{TGA}

TGA curves of the raw and thermally treated clay mineral samples are shown in Figure 5. Regarding the raw clay minerals and, at first, the Pal sample, three distinct weight loss steps can be observed in the TGA curve for the studied range of temperatures (12\% total weight loss). The first step is determined at about $60^{\circ} \mathrm{C}$ and has to do with the elimination of the interparticle adsorbed water, the second step is found at about $170^{\circ} \mathrm{C}$ and is assigned to the thermal dehydration of the sample, while an extra weight loss step appears at a higher temperature region $\left(340-420^{\circ} \mathrm{C}\right)$ (Frost and Ding 2003). Two considerations can be used for this step according to the literature. The first one is attributed to the dehydroxylation of the $\mathrm{OH}$ units from the octahedral $\mathrm{Fe}$ and $\mathrm{Al}$, and the second one (more likely) to irreversible dehydration of residual bound water. On the other hand, regarding the Sep sample, three weight loss steps may also be detected for the studied range of temperatures ( $8 \%$ total weight loss). The first step takes place at about $50^{\circ} \mathrm{C}$ and is attributed to the loss of remaining adsorbed water on the sample surface, the second step is determined just above $240^{\circ} \mathrm{C}$ and corresponds to the loss of hydration water, while a third step could also be considered at the temperature region 450$500^{\circ} \mathrm{C}$ and has to do with the loss of coordination water (Frost and Ding 2003). Regarding the thermally treated clay minerals samples, in these cases, the weight loss was found quite reduced compared to the corresponding raw samples 
since these samples had already undergone a thermal treatment at $400^{\circ} \mathrm{C}$. TGA analysis was performed until $600^{\circ} \mathrm{C}$ and in

270 both of the samples the adsorbed water molecules were degraded until $400^{\circ} \mathrm{C}$, while a small amount of the structural

271 water remained in the samples. The partial loss of adsorbed water at $400^{\circ} \mathrm{C}$ was also verified at FT-IR spectra.

\section{$272 \quad$ 3.1.6 Zeta potential}

273 The zeta potential distribution (Fig. 6) comes in agreement with previous experimental studies (Alshameri et al. 2018;

274 Abrougui et al. 2019). Specifically, the zeta-potential of raw and thermally modified samples was negative at the whole

$275 \mathrm{pH}$ range examined (4-11). This can be attributed to the isomorphous substitutions of $\mathrm{Al}^{3+}$ or $^{\mathrm{Mg}^{2+}}$ with $\mathrm{Si}^{4+}$ on octahedral

276 sheets of minerals, as well as to the potential exchange of monovalent ions with divalent ones, which affect minerals'

277 electrochemistry of solid/liquid interface (Alshameri et al. 2018; Abrougui et al. 2019) . That resulted in more negatively

278 charged interface with $\mathrm{pH}$ increase, rendering all of the examined materials be promising adsorbents for cations,

279 especially at $\mathrm{pH}$ values $>5$. Moreover, the thermal treatment had impact on the negative charge of the materials as well,

280 since T-Pal and T-Sep samples presented more negative values than the raw samples.

\section{$281 \quad$ 3.1.7 XRF analysis}

$282 \mathrm{XRF}$ analysis (Table 3) revealed that the chemical composition of the samples comprises mainly $\mathrm{SiO}_{2}(62-65 \%)$ and $283 \mathrm{MgO}(17-25 \%)$, while Pal and T-Pal samples were also rich in $\mathrm{Fe}(<9 \%)$ due to their deposit lithologies (Kastritis et al. 284 2003). The main oxides ( $\mathrm{Si}, \mathrm{Al}, \mathrm{Mg}$ and $\mathrm{Fe}$ ) were observed to remain more-or-less constant following thermal treatment 285 although a slight increase was seen in $\mathrm{T}-\mathrm{Sep}$ and $\mathrm{SiO}_{2}$ and $\mathrm{MgO}$ decreased slightly in T-Pal. This may be attributed either the sample heterogeneity or structural rearrangements that took place after thermal treatment. Oxide percentages remained stable after $\mathrm{NH}_{4}{ }^{+}-\mathrm{N}$ adsorption thus indicating that all the ions present are exchangeable with $\mathrm{NH}_{4}{ }^{+}$without strong preferences to one particular ion, verifying that ion exchange is essential mechanism at ammonium removal. Moreover, due to the low concentration of $\mathrm{NH}_{4}{ }^{+}$, the potential \%mass that could be ion-exchanged may be below the detection limits of the XRF equipment.

Table 3. Composition of main oxides and loss of ignition (LOI) of Pal, Sep, T-Pal, T-Sep before and after adsorption 292 (sample/ $\left./ \mathrm{NH}_{4}{ }^{+}\right)$with XRF analysis.

\begin{tabular}{|c|c|c|c|c|c|c|c|c|c|}
\hline \multirow[b]{2}{*}{ Samples } & \multicolumn{9}{|c|}{ Main Oxides (\% mass) } \\
\hline & $\mathrm{SiO}_{2}$ & $\mathrm{Al}_{2} \mathrm{O}_{3}$ & MgO & $\mathrm{CaO}$ & $\mathrm{Na}_{2} \mathrm{O}$ & $\mathrm{K}_{2} \mathrm{O}$ & MnO & $\mathrm{Fe}_{2} \mathrm{O}_{3}$ & LOI \\
\hline Pal & 63.69 & 1.10 & 19.78 & 0.33 & 0.06 & 0.04 & 0.41 & 9.36 & 10.00 \\
\hline Sep & 63.55 & 0.11 & 20.37 & 0.92 & 0.06 & 0.01 & 0.15 & 1.09 & 15.31 \\
\hline T-Pal & 62.94 & 1.10 & 18.79 & 0.45 & 0.07 & 0.06 & 0.61 & 13.35 & 8.28 \\
\hline T-Sep & 64.60 & 0.23 & 25.16 & 2.11 & 0.07 & 0.01 & 0.19 & 1.55 & 8.61 \\
\hline $\mathrm{Pal} / \mathrm{NH}_{4}^{+}$ & 62.58 & 1.01 & 17.86 & 0.28 & 0.06 & 0.04 & 0.42 & 9.57 & 12.35 \\
\hline $\mathrm{Sep} / \mathrm{NH}_{4}{ }^{+}$ & 65.18 & 0.13 & 24.41 & 1.61 & 0.04 & 0.01 & 0.15 & 1.25 & 11.17 \\
\hline
\end{tabular}




\begin{tabular}{cccccccccc}
\hline T-Pal $/ \mathrm{NH}_{4}{ }^{+}$ & 62.16 & 1.03 & 17.79 & 0.50 & 0.06 & 0.06 & 0.60 & 13.34 & 7.94 \\
T-Sep $/ \mathrm{NH}_{4}{ }^{+}$ & 63.34 & 0.23 & 24.85 & 2.07 & 0.06 & 0.01 & 0.19 & 1.54 & 9.36 \\
\hline
\end{tabular}

3.1.7 Thermal treatment effect and proposed $\mathrm{NH}_{4}{ }^{+}-\mathrm{N}$ removal mechanism on raw and thermally modified Pal and

In order to better understand the insight of $\mathrm{NH}_{4}{ }^{+}-\mathrm{N}$ removal mechanism onto Pal, Sep, T-Pal and T-Sep, the observations from characterization methods were evaluated. So far, it was reported that ion exchange between $\mathrm{Na}^{+}, \mathrm{Ca}^{2+}$ or $\mathrm{K}^{+}$with $\mathrm{NH}_{4}{ }^{+}$is the primary mechanism for ammonium removal (He et al. 2016; Alshameri et al. 2018). However, the XRF results did not indicate significant reduction at \%mass of the exchangeable cations of the adsorbents after $\mathrm{NH}_{4}{ }^{+}-\mathrm{N}$ adsorption (Table 3). This implied either that all the cations are exchangeable with ammonium as expressed in Equation 8, or that ion exchange partially contributes to ammonium removal on raw and thermally modified fibrous clay minerals.

$\mathrm{Na}^{+}, \mathrm{K}^{+}, \mathrm{Ca}^{2+}{ }_{(\text {Pal, Sep, T-Pal, T-Sep) }}+\mathrm{NH}_{4}{ }^{+}-\mathrm{N}_{(\text {aq. })} \leftrightarrow \mathrm{Na}^{+}, \mathrm{K}^{+}, \mathrm{Ca}^{2+}{ }_{\text {(aq.) }}+\mathrm{NH}_{4}{ }^{+}-\mathrm{N}_{(\text {Pal, Sep, T-Pal, T-Sep) }}$

On the other hand, the XRD patterns and FT-IR spectra of Pal and T-Pal verified the surficial interactions of $\mathrm{NH}_{4}{ }^{+}$with negatively charged active sites of Pal and T-Pal (Fig. 1,4), because of the decreased intensity of the XRD reflections of Pal and T-Pal after $\mathrm{NH}_{4}{ }^{+}-\mathrm{N}$ adsorption, highlighting the ammonium bonding on the surface. The FT-IR spectra verified the results obtained from XRD, since a new band was created at $1380 \mathrm{~cm}^{-1}$ for the Pal and T-Pal samples after $\mathrm{NH}_{4}{ }^{+}-\mathrm{N}$ adsorption, which is referred to surficial N-H bonding. Moreover, the BET analysis indicated that the SSA of the Pal sample was decreased after thermal treatment (T-Pal), nevertheless, according to the zeta potential distribution, T-Pal was more negatively charged than $\mathrm{Pal}$ at $\mathrm{pH}$ range 4-11. Potentially the rearrangement that thermal treatment emerged and was observed (Fig. 3), gradually increased the number of exchangeable cations (Chen et al. 2011b), making T-Pal a promising adsorbent for cations, such as ammonium, by enhancing its ion exchange capacity in combination with its surficial interactions.

On the contrary, Sep and T-Sep samples characteristics were differentiated from Pal and T-Pal. Precisely, the XRD reflections of Sep and T-Sep samples were increased after $\mathrm{NH}_{4}{ }^{+}-\mathrm{N}$ adsorption, revealing that potentially the interactions between sepiolite samples and ammonium are not mainly surficial. The FT-IR spectra also verified this case, since no notable shiftings or new bands occurred after $\mathrm{NH}_{4}{ }^{+}-\mathrm{N}$ adsorption. Moreover, $\mathrm{T}$-Sep presented an increase in total pore volume $\left(0.32 \mathrm{~cm}^{3} / \mathrm{g}\right)$ and pore diameter $\left(10.4 \mathrm{~cm}^{3} / \mathrm{g}\right)$ compared to Sep $\left(0.24\right.$ and $6.2 \mathrm{~cm}^{3} / \mathrm{g}$ respectively), which can be attributed to the inner channels breaking due to the removal of structural $\mathrm{Mg}$. The $\mathrm{Mg}-\mathrm{O}-\mathrm{Si}$ and $\mathrm{Mg}-\mathrm{OH}$ bonding proved to be broken at the FT-IR spectra, as was mentioned in section 3.1.4. All these structural changes in combination with the 
negative charge at a wide range of $\mathrm{pH}$, render the inner space and surface of Sep playing a key role at $\mathrm{NH}_{4}{ }^{+}-\mathrm{N}$ adsorption, while T-Sep adsorption capacity seems to be enhanced, due to the more negatively charged surface than Sep and the increase of the pores characteristics as well.

\subsection{Batch experiments}

\subsubsection{Effect of adsorbent dosage and initial concentration}

The effect of Pal and Sep dosage on $\mathrm{NH}_{4}{ }^{+}-\mathrm{N}$ removal was examined for various initial concentrations of the pollutant. It was obtained that higher adsorbent dosages lead to higher $\mathrm{NH}_{4}{ }^{+}-\mathrm{N}$ removal for all the initial $\mathrm{NH}_{4}{ }^{+}-\mathrm{N}$ concentrations examined for both examined dosages of Pal and Sep (Fig. 7a, b). These results were attributed to the high specific surface area of both clay minerals which provides numerous, readily-available active sites for $\mathrm{NH}_{4}{ }^{+}-\mathrm{N}$ to be adsorbed (Alshameri et al. 2018). Specifically, the dosage of $4 \mathrm{~g}$ Pal or Sep adsorbent in $200 \mathrm{ml}$ solution was found to be the most effective, especially for the removal of 1 or $2 \mathrm{mg} \mathrm{NH}_{4}{ }^{+}$-N $/ \mathrm{L}$ below the permitted limit for drinking water $(<0.5 \mathrm{mg} / \mathrm{L})$. The kinetic behavior of the highest examined adsorbent dosage $(4 \mathrm{~g})$ for all the initial $\mathrm{NH}_{4}{ }^{+}-\mathrm{N}$ concentrations examined is shown in Figure 8.

Both Pal and Sep presented maximum $\mathrm{NH}_{4}{ }^{+}-\mathrm{N}$ removal efficiencies of $60-80 \%$ within the first 20 min for all $\mathrm{NH}_{4}{ }^{+}-\mathrm{N}$ concentrations tested. Specifically, the highest removal efficiency (76\%) of $\mathrm{Pal}$ was observed for lower initial $\mathrm{NH}_{4}{ }^{+}-\mathrm{N}$ concentrations ( 1 and $2 \mathrm{mg} / \mathrm{L}$ ), in contrast with Sep that presented $75-80 \%$ removal when $\mathrm{NH}_{4}{ }^{+}-\mathrm{N}$ ranged from 4 to 6 $\mathrm{mg} / \mathrm{L}$, although its removal capacity decreased for $8 \mathrm{mg} \mathrm{NH}{ }_{4}{ }^{+}$-N/L. Potentially, $\mathrm{NH}_{4}{ }^{+}$at low concentrations can contact with the most of Pal active sites, whereas Pal smaller basal space inhibits the excessed ammonium ions to entry in the interlayer space, leading to decreased $\mathrm{NH}_{4}{ }^{+}-\mathrm{N}$ removal at higher concentrations (Rytwo et al. 2000; Aydın Temel and Kuleyin 2016). On the other hand, Sep removal efficiency is higher for increased ammonium concentrations for constant $4 \mathrm{~g}$ of dosage. This may be attributed to the increased ratio of ammonium ions per $\mathrm{L}$, available to interact with Sep active sites into the solution, leading to enhanced adsorption capacity. However, since the $\mathrm{NH}_{4}{ }^{+}-\mathrm{N}$ removal efficiency of Sep for 4-6 mg NH${ }_{4}{ }^{+}-\mathrm{N} / \mathrm{L}$ had no significant variation, probably the adsorption capacity of the specific dosage is achieved, and there were not available active sites to interact with $8 \mathrm{mg} \mathrm{NH}_{4}{ }^{+}-\mathrm{N} / \mathrm{L}$.

To determine the effect of T-Pal and T-Sep dosage on the removal of $\mathrm{NH}_{4}{ }^{+}-\mathrm{N}$ of various concentrations, the batch experiments were performed by applying the optimum dose of each raw mineral (determined as $4.0 \mathrm{~g}$ ) for 1, 2, 4, 6 and 8 $\mathrm{mg} / \mathrm{L} \mathrm{NH}_{4}{ }^{+}-\mathrm{N}$ removal. The removal efficiencies of both Pal and Sep increased by $10-20 \%$ after thermal treatment, but also retained the tendency presented as raw materials, concerning the $\mathrm{NH}_{4}{ }^{+}-\mathrm{N}$ concentration increase (Fig. 9a, b). The 
efficiency increase can be attributed to the enhancement of negative charge that thermal treatment emerged according to the zeta potential results that can be attributed to water loss that alters and possibly slightly increases the interlayer space of both adsorbents (Zadaka-Amir et al. 2013). Specifically, T-Pal produced $85 \%$ removal of $2 \mathrm{mg} / \mathrm{L} \mathrm{NH}_{4}{ }^{+}-\mathrm{N}$ compared to 70-75\% removal by Pal due to potential ion exchange capacity increase after thermal treatment. The highest removal efficiencies of T- Sep was observed for 4 and $6 \mathrm{mg} / \mathrm{L} \mathrm{NH}_{4}{ }^{+}-\mathrm{N}$ concentrations, since the inner space was increased as the BET analysis reinsured, whereas thermal treatment did not notably enhance the mineral's removal efficiency for 1 or 2

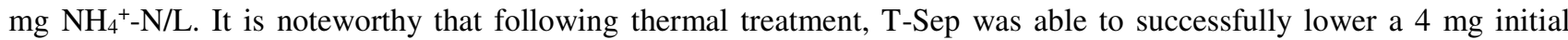
$\mathrm{NH}_{4}{ }^{+}-\mathrm{N} / \mathrm{L}$ concentration to below the permitted EU limit. The enhanced removal ability of T-Pal was apparent; however, final concentrations of ammonium were $0.1 \mathrm{mg} / \mathrm{L}$ above the permitted $\mathrm{EU}$ limits.

Compared to the most frequently used natural adsorbent for $\mathrm{NH}_{4}{ }^{+}-\mathrm{N}$; zeolite, the fibrous clay minerals presented close removal capacity with the study of Fu et al. (2020) or Kotoulas et al. (2019), despite the fact that zeolites decreased the $\mathrm{NH}_{4}{ }^{+}$-N below the E.U. limit. Nevertheless, the double adsorbent dosage from current study was used in the study of Kotoulas et al. (2019), whereas Fu et al. (2020) underwent zeolite two different modification methods for the removal of $5 \mathrm{mg} / \mathrm{L} \mathrm{NH}_{4}{ }^{+}-\mathrm{N}$. Under these conditions, the cost and operational difficulties were higher than the examined conditions of present study, indicating that the raw and thermally modified fibrous clay minerals can be comparable and competitive to examined zeolites for water treatment.

\subsubsection{Effect of $\mathrm{pH}$}

To examine the impact of $\mathrm{pH}$ on $\mathrm{NH}_{4}{ }^{+}-\mathrm{N}$ removal, the following conditions were applied: $4 \mathrm{~g}$ of adsorbent and $4 \mathrm{mg} / \mathrm{L}$ initial $\mathrm{NH}_{4}{ }^{+}-\mathrm{N}$ concentration were examined with $\mathrm{pH}$ values ranging from 2 to 11 . These conditions were deemed suitable as lower ammonium concentrations (1-2 mg/L) are effectively removed to levels below the legislated limit $(<0.5$ $\mathrm{mg} / \mathrm{L})$, and higher concentrations $(6-8 \mathrm{mg} / \mathrm{L})$ remained above this value after adsorption. The experimental results showed that the removal efficiency of all the adsorbents correlates positively to $\mathrm{pH}$ increase (Fig.10), since the adsorption procedure is enhanced up to the case of $\mathrm{pH} 9$, where it exceeds $85 \%$ for the thermally-treated mineral samples. This efficiency can be explained by the state of $\mathrm{NH}_{4}{ }^{+}$ions in water as at low $\mathrm{pH}$ values they are present in the $\mathrm{NH}_{4}{ }^{+}$form and at $\mathrm{pH}$ values above 8.5 they are present as ammonia $\left(\mathrm{NH}_{3 a q}\right)$. At very low $\mathrm{pH}$ values, the $\mathrm{H}^{+}$ions compete strongly with $\mathrm{NH}_{4}{ }^{+}$for available surface adsorption sites and interactions between adsorbent - adsorbate are inhibited.

374 Similar results were also recorded by Vu et al. (2017) who used biochar. It is likely that at $\mathrm{pH}$ values above 9, most of the $375 \mathrm{NH}_{4}{ }^{+}$is transformed to $\mathrm{NH}_{3(\text { aq) }}$ and the electrostatic attraction to clay minerals decreases (Vu et al. 2017; Pan et al. 2019). 
at higher $\mathrm{pH}$ values, interpreted the low removal efficiency of all the samples at $\mathrm{pH}$ range $2-5$. Moreover, at $\mathrm{pH} 6$ the zeta potential decreases more steeply than the lower $\mathrm{pH}$ values while at $\mathrm{pH} 7$ and $\mathrm{pH} 8$ the zeta potential remained almost stable. This may explain the reason why at $\mathrm{pH} 7$ the $\mathrm{NH}_{4}{ }^{+}-\mathrm{N}$ removal efficiency is not the highest, like was noted in the study of Alhameri et al. (2018), highlighting the samples' origin dependence on interfacial properties. Moreover, despite the fact at $\mathrm{pH}>9$ the zeta potential becomes more negative, is not equalized with enhanced ammonium removal, potentially due to ammonium alteration to $\mathrm{NH}_{3(\mathrm{aq})}$ as it was abovementioned.

\subsubsection{Saturation test}

The potential reusability of Pal, Sep, T-Pal and T-Sep as $\mathrm{NH}_{4}{ }^{+}-\mathrm{N}$ adsorbents was examined using $4 \mathrm{~g}$ of each adsorbent, 4 $\mathrm{mg} / \mathrm{L}$ ammonium solution, and natural $\mathrm{pH}$ solution (5.5). The saturation test verified the effects of the thermal treatment on the fibrous clay minerals (Fig. 11). T-Pal and T-Sep achieved $81 \%$ and $85 \%$ removal, respectively, within the first 24 $\mathrm{h}$ and these rates remained almost constant until the third adsorption cycle (day 3). At $24 \mathrm{~h}$ the ammonium removal efficiency of Pal and Sep samples was already declined. This could be attributed to the fine particle size of the samples in combination with the limited adsorbent dosage and relatively low ammonium initial concentration. The finest the particle size is, the sooner desorption rates can be achieved, especially under intense agitation (Keyes and Silcox 1994). Both untreated minerals achieved 55\% removal $(0.48 \pm 0.05 \mathrm{mg} / \mathrm{g})$ in $24 \mathrm{~h}$, but only the removal pace of Sep remained almost stable for two more cycles, whereas Pal adsorption capacity decreased by up to $17 \%$ from the second day. According to this saturation test, T-Pal or T-Sep can be characterized as sufficient adsorbents for groundwater treatment that adsorbed $0.64-0.68 \pm 0.02 \mathrm{mg} / \mathrm{g} \mathrm{NH}_{4}{ }^{+}-\mathrm{N}$ respectively, degrading the $\mathrm{NH}_{4}{ }^{+}-\mathrm{N}$ concentration to the acceptable drinking limits during $24 \mathrm{~h}$. Nevertheless, none of the raw or thermally-treated clay minerals tested presented sufficient reusability for treatment of water for $\mathrm{NH}_{4}{ }^{+}-\mathrm{N}$, but all could be effectively reused for pre-treatment. Pal and Sep both removed 4.28 $\pm 0.02 \mathrm{mg} \mathrm{NH}{ }_{4}{ }^{+} \mathrm{N} / \mathrm{g}$ by the end of the saturation test (day 22), while T-Pal and T-Sep removed $5.95 \pm 0.04 \mathrm{mg} / \mathrm{g} \mathrm{NH}_{4}{ }^{+}-\mathrm{N}$ in the same period. The multiple adsorption cycles were attributed to the primary saturation of the external surfaces of the adsorbents. When this point was reached the adsorbate enters into the adsorbent's interlayer space and pores (Alshameri et al. 2018). No research is available on $\mathrm{NH}_{4}{ }^{+}-\mathrm{N}$ saturation in Pal and Sep to compare the results.

\subsection{Adsorption Isotherms}

The linear forms of the Langmuir and Freundlich isotherms were applied to Pal, Sep, T-Sep and T-Pal to determine the variation of their removal capacities with increased $\mathrm{NH}_{4}{ }^{+} \mathrm{N}$ initial concentrations. Both Langmuir and Freundlich isotherms presented a good fit to all the adsorbents examined since the $R^{2}$ value in all cases is $>0.95$ (Table 4). 
$R^{2}$ values of 0.974 and 0.991 , respectively, which renders the adsorption a heterogeneous procedure. On the other hand, the adsorption behavior of Sep differentiated slightly after thermal treatment as the Langmuir isotherm for Sep presented a better fit for $\mathrm{NH}_{4}{ }^{+}-\mathrm{N}$ adsorption, but for T-Sep adsorption is expressed better by the Freundlich isotherm with $R^{2} 0.998$ (compared to $R^{2} 0.991$ for the Langmuir isotherm). This result revealed the preference of almost monolayer $\mathrm{NH}_{4}{ }^{+}-\mathrm{N}$ adsorption on the Sep mineral, which potentially became heterogeneous for T-Sep. This change was probably attributed to the increased number micropores occurring after calcination as verified by the BET analysis.

Table 4. Comparison of adsorption isotherms constants for Pal, Sep, T-Pal, T-Sep.

\section{Langmuir isotherm}

\section{Freundlich isotherm}

\begin{tabular}{llllllllll}
\hline & Pal & Sep & T-Pal & T-Sep & & Pal & Sep & T-Pal & T-Sep \\
\hline $\boldsymbol{q}_{\max }(\mathrm{mg} / \mathrm{g})$ & 0.38 & 0.31 & 0.44 & 0.93 & $\boldsymbol{1} / \boldsymbol{n}$ & 0.839 & 0.642 & 0.6697 & 0.8750 \\
$\boldsymbol{K}_{\boldsymbol{L}}$ & 0.353 & 0.901 & 0.657 & 0.144 & $\boldsymbol{K}_{\boldsymbol{F}}$ & 0.099 & 0.125 & 0.1592 & 0.1132 \\
$\boldsymbol{R}^{2}$ & 0.952 & 0.993 & 0.954 & 0.991 & $\boldsymbol{R}^{2}$ & 0.974 & 0.954 & 0.991 & 0.998 \\
& & & & & & & & &
\end{tabular}

\section{$414 \quad 3.4$ Adsorption kinetic models}

415 The relative parameters of all applied kinetic models (pseudo-first order, pseudo-second order and intra particle diffusion) are presented in Table 5. The correlation coefficients $\left(R^{2}>0.99\right)$ showed that the pseudo-second order fit the data better than the other two models. These results were in agreement with FT-IR spectra and other studies that examined $\mathrm{NH}_{4}{ }^{+}-\mathrm{N}$ removal from aqueous solutions using aluminosilicate adsorbents and concluded chemisorption as adequately expressing $\mathrm{NH}_{4}{ }^{+}-\mathrm{N}$ removal on clay minerals (Sun et al. 2017; Alshameri et al. 2018). Adsorption capacity at equilibrium $\left(q_{e}\right)$ is a significant parameter of each model's evaluation. From each kinetic model result a $q_{e c a l}$ value, is 421 determined from the intercept and the slope of the pseudo-first and pseudo-second order plots, respectively, is further compared to the maximum removal rate at equilibrium $\left(q_{\text {exp }}\right)$. In all cases, the $q_{\text {eexp }}$ variables were in full agreement with 423 the $q_{\text {ecal }}$ from the pseudo-second order model, compare to pseudo - first order $q_{\text {ecal }}$ (Table 5), rendering the pseudo second order the appropriate kinetic mechanism for $\mathrm{NH}_{4}{ }^{+}-\mathrm{N}$ adsorption on the studied adsorbents.

425 The Weber-Morris model is parted from two linear segments (Table 5). In the first stage $\mathrm{NH}_{4}{ }^{+}-\mathrm{N}$ diffuses from the 426 aqueous solution to liquid:solid interface, while in the second stage the adsorbate diffuses from the interface into the adsorbent pores Weber and Morris (1963). In all cases, Stage $1 k_{i d}>$ Stage $2 k_{i d}$, thus indicating the rapid diffusion of $\mathrm{NH}_{4}{ }^{+}$-N at the solids interface, compared to a very slow rate diffusion in their inner pores (Genethliou et al. 2021). 
Pseudo-first order

Pseudo-second order

Weber Morris model

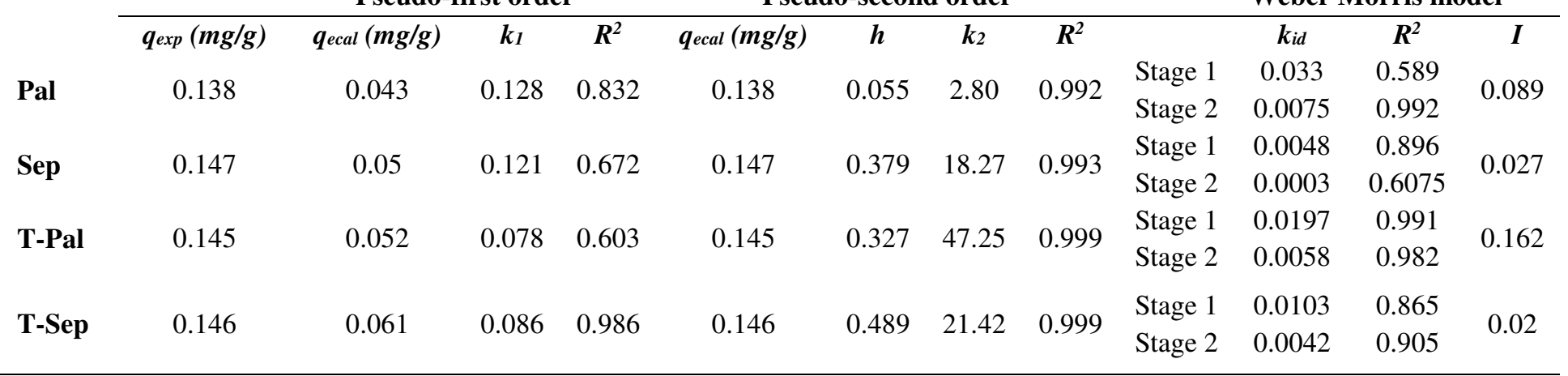

431

\subsection{Real-water application of the adsorbents}

433 The raw and thermally treated samples were applied in the optimal dosage determined at the previous batch experiments 434 (4 g adsorbent), for $4 \mathrm{mg} / \mathrm{L} \mathrm{NH}_{4}{ }^{+}-\mathrm{N}$ degradation from ammonium rich tap water. According to Table 1, the water 435 consistency is enriched in potentially competitive cations for $\mathrm{NH}_{4}^{+}$, such as $\mathrm{Na}^{+}, \mathrm{Ca}^{2+}$ and $\mathrm{Mg}^{2+}$, as well as is extremely 436 hard water (WHO, 2011). Under these conditions, Pal and T-Pal removal efficiency for $\mathrm{NH}_{4}{ }^{+}-\mathrm{N}_{\text {was }}$ strongly influenced, 437 since it was decreased up to $50 \%$ for both of the samples (Fig. 12). Palygorskite clay mineral has reported in other studies 438 strong ion exchange affinity for $\mathrm{Ca}^{2+}$ spontaneously (Lazaratou et al. 2020a), which can be inhibiting factor for 439 ammonium removal (Yin and Kong 2014). Sep and T-Sep samples' removal efficiency for $\mathrm{NH}_{4}{ }^{+}-\mathrm{N}$ was impacted as 440 well; however, $25 \%$ and 20\% decrease was noted (Fig.10), rendering Sep and T-Sep with stronger affinity for ammonium 441 than Pal and T-Pal samples. Despite the decline at $\mathrm{NH}_{4}^{+}-\mathrm{N}$ removal capacity of the examined samples, further 442 investigation must be conducted, since there is limited literature about natural water systems and how their composition, 443 or the concentration of the existed ionic species influence interactions between ammonium and clay minerals' interface.

\section{4. Conclusions}

445 Raw and thermally-treated palygorskite (Pal / T-Pal) and sepiolite (Sep / T-Sep) were applied as low concentration $\mathrm{NH}_{4}{ }^{+}-$

$446 \mathrm{~N}$ adsorbents from aqueous solutions. The extensive characterization of the samples verified the thermal treatment effect 447 and the expected structural rearrangements. Pal, Sep, T-Pal and T-Sep presented different adsorptive properties, 448 especially after thermal treatment, since Pal and T-Pal mostly interact with $\mathrm{NH}_{4}{ }^{+}-\mathrm{N}$ on its surface, conversely to Sep and 449 T-Sep where the inner interactions are dominant. According to a series of batch kinetic experiments, $\mathrm{NH}_{4}{ }^{+}-\mathrm{N}_{\text {removal }}$ 450 process was quite rapid and preferable at $\mathrm{pH} 4-9$. Removal rates were adequate to reduce $\mathrm{NH}_{4}{ }^{+}-\mathrm{N}$ concentrations to 
below the permitted EU limit for drinking water for initial $\mathrm{NH}_{4}{ }^{+}-\mathrm{N}$ concentrations of 1 and $2 \mathrm{mg} / \mathrm{L}$, thus rendering Pal,

Sep, T-Pal and T-Sep suitable materials for the treatment of most contaminated aquifers. T-Sep can also be used to treat groundwaters with initial $\mathrm{NH}_{4}{ }^{+}-\mathrm{N}$ concentration of $4 \mathrm{mg} / \mathrm{L}$. Nevertheless, the presence of competitive ions such as $\mathrm{Ca}^{2+}$ strongly deteriorate ammonium interaction with Pal and T-Pal, indicating that it's application in very hard waters may prohibit $\mathrm{NH}_{4}{ }^{+}-\mathrm{N}$ degradation. On the contrary, Sep and T-Sep may not be strongly influenced from competitive ions presentation, but achieved decreased $\mathrm{NH}_{4}{ }^{+}-\mathrm{N}$ removal up to $25 \%$.

The saturation test indicated that T-Pal and T-Sep are effective at $\mathrm{NH}_{4}{ }^{+}-\mathrm{N}$ removal for $24 \mathrm{~h}$ but cannot be reused for water treatment when solutions are highly contaminated $\left(4 \mathrm{mg} \mathrm{NH}_{4}{ }^{+}-\mathrm{N} / \mathrm{L}\right)$. Nevertheless, Pal, Sep, T-Pal and T-Sep can be applied as suitable pre-treatment materials for multiple times. Mechanical and kinetic properties of the procedure were determined using the linear forms of Langmuir and Freundlich isotherm models, as well as the linear form of pseudofirst, pseudo-second order and Weber-Morris kinetic models. All the above-mentioned models fit to the data of each tested mineral sample, however, the Freundlich isotherm and pseudo-second kinetic models presented better fits for all samples, thus indicating the heterogeneous nature of adsorption via strong chemical bonds (chemisorption).

\section{Acknowledgements}

This research did not receive any specific grant from funding agencies in the public, commercial, or not-for-profit sectors. The authors would like to thank Dr. Paraskevi Lampropoulou from University of Patras for XRD analysis, Dr. Vayia Xanthopoulou from the Laboratory of Electron Microscopy and Microanalysis at University of Patras for the XRF analysis and Dr. C. Anastasopoulos from Advanced Polymers \& Hybrid Nanomaterials Research Laboratory of Chemistry Department at University of Patras for FT-IR samples preparation. Also, the authors acknowledge Dr.

470 Vassilios Dracopoulos from FORTH, Patras for the SEM images analysis.

\section{Authors' contributions}

472 Christina V. Lazaratou: Investigation, Methodology, Visualization, Writing-original draft Irene E. Triantaphyllidou: 473 Methodology, Visualization, Writing- Reviewing and editing Ioannis Pantelidis: Methodology, Visualization Dimitrios 474 A. Chalkias: Methodology, Writing-original draft George Kakogiannis: Resources Dimitrios V. Vayenas: 475 Conceptualization, Resources, Project administration, Writing- Reviewing and editing Dimitrios Papoulis: 476 Conceptualization, Resources, Supervision

477 Data availability: The datasets used and/or analyzed during the current study are available from the corresponding author on reasonable request. 


\section{Declarations}

481 Ethics approval and consent to participate: Not applicable

482 Consent for publication: Not applicable

483 Competing interests: The authors declare no competing interests.

Abrougui MM, Lopez-Lopez MT, Duran JDG (2019) Mechanical properties of magnetic gels containing rod-like composite particles. Phil Trans R Soc A 377:20180218. https://doi.org/10.1098/rsta.2018.0218

Alshameri A, He H, Zhu J, et al (2018) Adsorption of ammonium by different natural clay minerals: Characterization, kinetics and adsorption isotherms. Applied Clay Science 159:83-93. https://doi.org/10.1016/j.clay.2017.11.007

Aydın Temel F, Kuleyin A (2016) Ammonium removal from landfill leachate using natural zeolite: kinetic, equilibrium, and thermodynamic studies. Desalination and Water Treatment 57:23873-23892. https://doi.org/10.1080/19443994.2015.1136964

Balci S (1999) Effect of heating and acid pre-treatment on pore size distribution of sepiolite. Clay Minerals 34:647655

Blanco C, González F, Pesquera C, et al (1989) Differences Between One Aluminic Palygorskite and Another Magnesic by Infrared Spectroscopy. Spectroscopy Letters 22:659-673. https://doi.org/10.1080/00387018908053926

Böhlke JK, Smith RL, Miller DN (2006) Ammonium transport and reaction in contaminated groundwater: Application of isotope tracers and isotope fractionation studies: $\mathrm{NH}_{4}{ }^{+}$TRANSPORT IN CONTAMINATED GROUNDWATER. Water Resour Res 42:. https://doi.org/10.1029/2005WR004349

Brigatti, M.F., Galán, E., Theng, B.K.G., 2013. Structure and mineralogy of clay minerals. In: Bergaya, F., Lagaly, G. (Eds.), Handbook of Clay Science. Vol. 5. Elsevier, pp.21-81 (Chapter 2). 

356.

Bu X, Zhang G, Guo Y (2011) Thermal modified palygorskite: Preparation, characterization, and application for cationic dye-containing wastewater purification. Desalination and Water Treatment 30:339-347. https://doi.org/10.5004/dwt.2011.2242

Cases JM (1991) Evolution of the Porous Structure and Surface Area of Palygorskite Under Vacuum Thermal Treatment. Clays and Clay Minerals 39:191-201. https://doi.org/10.1346/CCMN.1991.0390211

Chen H, Zhao J, Zhong A, Jin Y (2011a) Removal capacity and adsorption mechanism of heat-treated palygorskite clay for methylene blue. Chemical Engineering Journal 174:143-150. https://doi.org/10.1016/j.cej.2011.08.062

Chen T, Liu H, Li J, et al (2011b) Effect of thermal treatment on adsorption-desorption of ammonia and sulfur dioxide on palygorskite: Change of surface acid-alkali properties. Chemical Engineering Journal 166:1017-1021. https://doi.org/10.1016/j.cej.2010.11.094

Frost RL, Ding Z (2003) Controlled rate thermal analysis and differential scanning calorimetry of sepiolites and palygorskites. Thermochimica Acta 397:119-128. https://doi.org/10.1016/S0040-6031(02)00228-9

Fu H, Li Y, Yu Z, et al (2020) Ammonium removal using a calcined natural zeolite modified with sodium nitrate. Journal of Hazardous Materials 393:122481. https://doi.org/10.1016/j.jhazmat.2020.122481

Galan E (1996) Properties and applications of palygorskite-sepiolite clays. Clay miner 31:443-453. https://doi.org/10.1180/claymin.1996.031.4.01 
He Y, Lin H, Dong Y, et al (2016) Simultaneous removal of ammonium and phosphate by alkaline-activated and lanthanum-impregnated zeolite. Chemosphere 164:387-395. https://doi.org/10.1016/j.chemosphere.2016.08.110

Hou J, Huang L, Yang Z, et al (2016) Adsorption of ammonium on biochar prepared from giant reed. Environ Sci Pollut Res 23:19107-19115. https://doi.org/10.1007/s11356-016-7084-4

Karri RR, Jayakumar NS, Sahu JN (2017) Modelling of fluidised-bed reactor by differential evolution optimization for phenol removal using coconut shells based activated carbon. Journal of Molecular Liquids 231:249-262. https://doi.org/10.1016/j.molliq.2017.02.003

Kastritis ID, Kacandes GH, Mposkos E (2003) The palygorskite and Mg-Fe-smectite clay deposits of the Ventzia basin, western Macedonia, Greece. Mineral exploration and Sustainable Development 4

Keyes BR, Silcox GD (1994) Fundamental Study of the Thermal Desorption of Toluene from Montmorillonite Clay Particles. Environ Sci Technol 28:840-849. https://doi.org/10.1021/es00054a015

Kotoulas A, Agathou D, Triantaphyllidou I, et al (2019) Zeolite as a Potential Medium for Ammonium Recovery and Second Cheese Whey Treatment. Water 11:136. https://doi.org/10.3390/w11010136

Lainé M, Balan E, Allard T, et al (2017) Reaction mechanisms in swelling clays under ionizing radiation: influence of the water amount and of the nature of the clay mineral. RSC Adv 7:526-534. https://doi.org/10.1039/C6RA24861F

Lazaratou CV, Panagiotaras D, Panagopoulos G, et al (2020a) Ca treated Palygorskite and Halloysite clay minerals for Ferrous Iron $(\mathrm{Fe}+2)$ removal from water systems. Environmental Technology \& Innovation 19:100961. https://doi.org/10.1016/j.eti.2020.100961

Lazaratou CV, Vayenas DV, Papoulis D (2020b) The role of clays, clay minerals and clay-based materials for nitrate removal from water systems: A review. Applied Clay Science 185:105377. https://doi.org/10.1016/j.clay.2019.105377

Madejová, J., Gates, W.P., Petit, S., 2017. Infrared and Raman sprectroscopies of Clay Minerals. In: Gates, W.P, Kloprogge, J.T., Madejova, J., Bergaya, F. (Eds.), Developments in Clay Science Volume 8. Elsevier, pp. 143-149 
Marler B, Oberhagemann U, Vortmann S, Gies H (1996) Influence of the sorbate type on the XRD peak intensities of loaded MCM-41. Microporous Materials 6:375-383. https://doi.org/10.1016/0927-6513(96)00016-8

Miura A, Nakazawa K, Takei T, et al (2012) Acid-, base-, and heat-induced degradation behavior of Chinese and Uses. In: Developments in Clay Science. Elsevier, pp 85-99

Myriam M (1998) Structural and Textural Modifications of Palygorskite and Sepiolite under Acid Treatment. Clays and Clay Minerals 46:225-231. https://doi.org/10.1346/CCMN.1998.0460301

Pan M, Zhang M, Zou X, et al (2019) The investigation into the adsorption removal of ammonium by natural and modified zeolites: kinetics, isotherms, and thermodynamics. WSA 45:. https://doi.org/10.17159/wsa/2019.v45.i4.7546

Papoulis D, Somalakidi K, Todorova N, et al (2019) Sepiolite/TiO 2 and metal ion modified sepiolite/TiO 2 nanocomposites: synthesis, characterization and photocatalytic activity in abatement of NOx gases. Applied Clay Science 179:105156. https://doi.org/10.1016/j.clay.2019.105156

Perraki Th, Orfanoudaki A (2008) Study of raw and thermally treated sepiolite from the Mantoudi area, Euboea, Greece: X-ray diffraction, TG/DTG/DTA and FTIR investigations. J Therm Anal Calorim 91:589-593. https://doi.org/10.1007/s10973-007-8329-8

Rozic M (2000) Ammoniacal nitrogen removal from water by treatment with clays and zeolites. Water Research 34:3675-3681. https://doi.org/10.1016/S0043-1354(00)00113-5

Rusydi AF, Onodera S-I, Saito M, et al (2020) Potential Sources of Ammonium-Nitrogen in the Coastal Groundwater Determined from a Combined Analysis of Nitrogen Isotope, Biological and Geological Parameters, and Land Use. Water 13:25. https://doi.org/10.3390/w13010025

Rytwo G, Nir S, Crespin M, Margulies L (2000) Adsorption and Interactions of Methyl Green with Montmorillonite and Sepiolite. Journal of Colloid and Interface Science 222:12-19. https://doi.org/10.1006/jcis.1999.6595 
Sun N, Shi W, Ma L, Yu S (2017) Investigations on the mechanism, kinetics and isotherms of ammonium and humic acid co-adsorption at low temperature by 4A-molecular sieves modified from attapulgite. RSC Adv 7:17095-17106. https://doi.org/10.1039/C7RA00268H

Svilović S, Rušić D, Bašić A (2010) Investigations of different kinetic models of copper ions sorption on zeolite 13X. Desalination 259:71-75. https://doi.org/10.1016/j.desal.2010.04.033

Verdouw, H, van Echteld, CJA, Dekkers, EMJ, (1978) Ammonia determination based on indophenol formation with sodium salicylate. Water Res. 12, 399-402. https:// doi.org/10.1016/0043-1354(78)90107-0.

World Health Organization (WHO), 2003. Ammonia in Drinking-water. Heal San Fr 2, in Drinking water, https://www.who.int/water_sanitation_health/dwq/chemicals/hardness.pdf (accessed 31/3/ 21) Recommendations, $1-240$. 

oil. Applied Clay Science 119:338-347. https://doi.org/10.1016/j.clay.2015.10.037

Yagub MT, Sen TK, Afroze S, Ang HM (2014) Dye and its removal from aqueous solution by adsorption: A review. Advances in Colloid and Interface Science 209:172-184. https://doi.org/10.1016/j.cis.2014.04.002

Yan W, Liu D, Tan D, et al (2012) FTIR spectroscopy study of the structure changes of palygorskite under heating. Spectrochimica Acta Part A: Molecular and Biomolecular https://doi.org/10.1016/j.saa.2012.07.085

Yang J-R, Wang Y, Chen H, Lyu Y-K (2019) Ammonium removal characteristics of an acid-resistant bacterium Acinetobacter sp. JR1 from pharmaceutical wastewater capable of heterotrophic nitrification-aerobic denitrification. Bioresource Technology 274:56-64. https://doi.org/10.1016/j.biortech.2018.10.052

Zadaka-Amir D, Bleiman N, Mishael YG (2013) Sepiolite as an effective natural porous adsorbent for surface oilspill. Microporous and Mesoporous Materials 169:153-159. https://doi.org/10.1016/j.micromeso.2012.11.002

Zeng J, Chabi K, Hu Y, et al (2020) Ammonium removal of biological roughing filter for rural drinking water pretreatment. Water Supply 20:2768-2778. https://doi.org/10.2166/ws.2020.171

Zhou CH, Zhou Q, Wu QQ, et al (2019) Modification, hybridization and applications of saponite: An overview. Applied Clay Science 168:136-154. https://doi.org/10.1016/j.clay.2018.11.002

Zuo Q, Gao X, Yang J, et al (2017) Investigation on the thermal activation of montmorillonite and its application for the removal of $\mathrm{U}(\mathrm{VI})$ in aqueous solution. Journal of the Taiwan Institute of Chemical Engineers 80:754-760. https://doi.org/10.1016/j.jtice.2017.09.016 


\section{Figure captions}

626 Figure 1. XRD patterns of a) Pal b) $\mathrm{T}-\mathrm{Pal}$ c) Sep and d) T-Sep before and after $\mathrm{NH}_{4}{ }^{+}-\mathrm{N}$ adsorption where $\mathrm{P}$ : 627 palygorskite, S: saponite, Sep: sepiolite, AnSep: sepiolite anhydrite and C: calcite.

628 Figure 2. Scanning Electron Microscopy (SEM) images of a) Pal b) Sep c) T-Pal and d) T-Sep at $200 \mathrm{~nm}$.

629 Figure 3. $\mathrm{N}_{2}$ sorption - desorption isotherms plot from BET analysis for Pal, Sep, T-Pal and T-Sep.

630 Figure 4. FT-IR spectra before and after $\mathrm{NH}_{4}{ }^{+}-\mathrm{N}$ adsorption of a) Pal b) T-Pal c) Sep and d) T-Sep.

631 Figure 5. TGA curves of Pal, Sep, T-Pal and T-Sep.

632 Figure 6. The zeta potential of Pal, Sep, T-Pal and T-Sep at pH range 4-11.

633 Figure 7. Maximum $\mathrm{NH}_{4}{ }^{+}-\mathrm{N}$ Removal Efficiency (\%) with 0.4, 0.8, 1.6 and $4 \mathrm{~g}$ a)Pal and b)Sep for $\mathrm{NH}_{4}{ }^{+}-\mathrm{N}$ 634 initial concentration 1, 2, 4, 6 and $8 \mathrm{mg} / \mathrm{L}$. The removal efficiency $(\%)$ is the mean value from duplicate 635 experiments.

636 Figure 8. The effect of initial concentration on $\mathrm{NH}_{4}{ }^{+}-\mathrm{N}$ removal by $4 \mathrm{~g}$ a) Pal and b) Sep.

637 Figure 9. The effect of initial concentration on $\mathrm{NH}_{4}{ }^{+}-\mathrm{N}$ removal by $4 \mathrm{~g}$ a) $\mathrm{T}$ - Pal and b) T-Sep.

638 Figure 10 . The effect of $\mathrm{pH}$ on $\mathrm{NH}_{4}{ }^{+}-\mathrm{N}$ removal by $4 \mathrm{~g}$ Pal, Sep, T- Pal and T-Sep. $\left(4 \mathrm{mg} \mathrm{NH}{ }_{4}{ }^{+}-\mathrm{N} / \mathrm{L}, \mathrm{V}=200\right.$ $639 \mathrm{ml}, 20 \mathrm{~min})$

640 Figure 11. Saturation test of $4 \mathrm{~g} \mathrm{Pal}$, Sep, T-Pal and T-Sep in $\mathrm{NH}_{4}{ }^{+}-\mathrm{N}$ solution. $\left(4 \mathrm{mg} \mathrm{NH}{ }^{+}-\mathrm{N} / \mathrm{L}, \mathrm{V}=200 \mathrm{ml}\right.$, $641 \mathrm{pH}=5.5)$

642 Figure 12. Removal efficiency (\%) of $4 \mathrm{~g}$ Pal, Sep, T-Pal and T-Sep in real water sample contaminated with 4 643 $\mathrm{mg} / \mathrm{L} \mathrm{NH}_{4}{ }^{+}-\mathrm{N}$. 
Figures
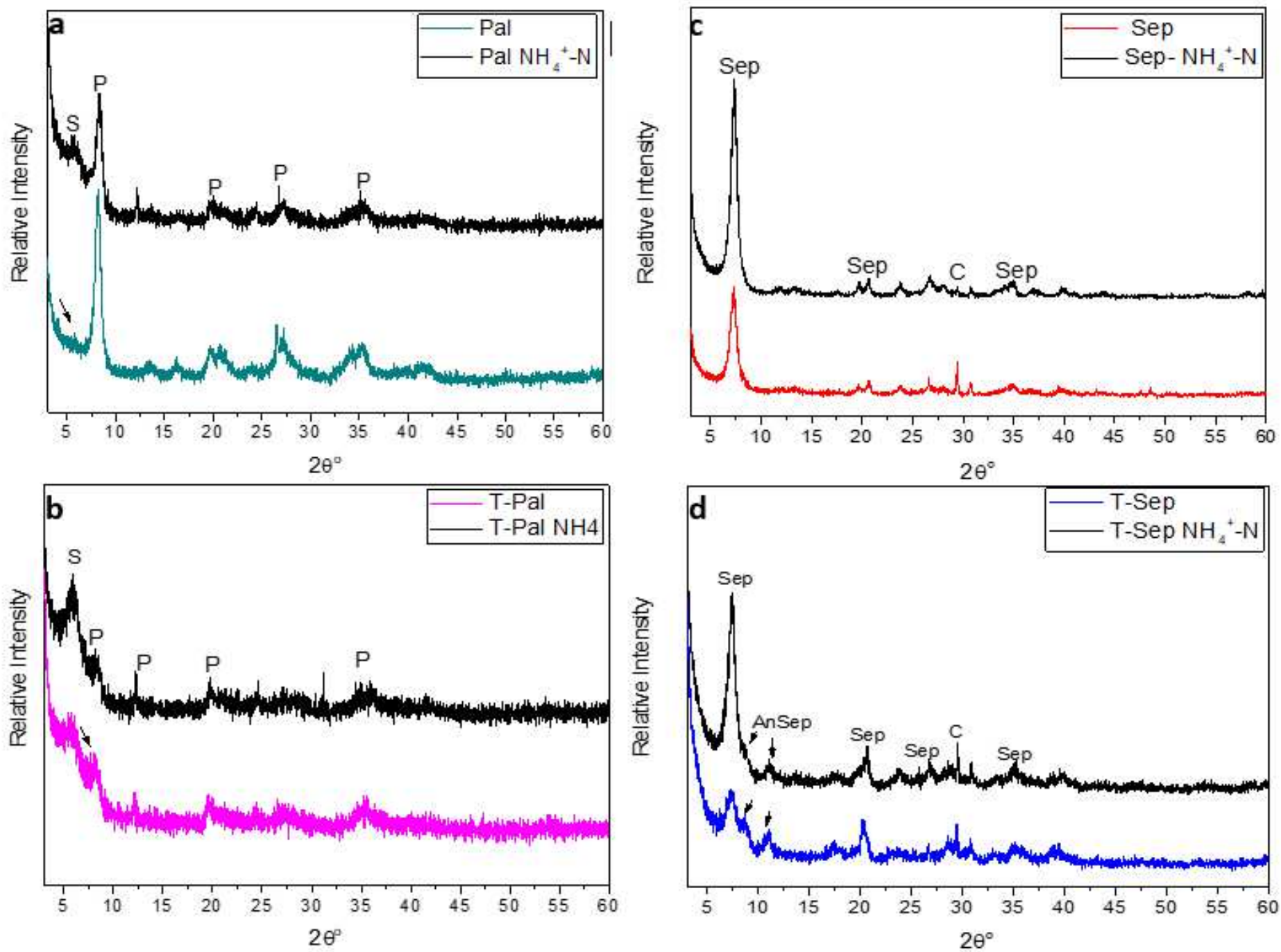

Figure 1

XRD patterns of a) Pal b) T -Pal c) Sep and d) T-Sep before and after NH4+-N adsorption where P: palygorskite, S: saponite, Sep: sepiolite, AnSep: sepiolite anhydrite and C: calcite. 

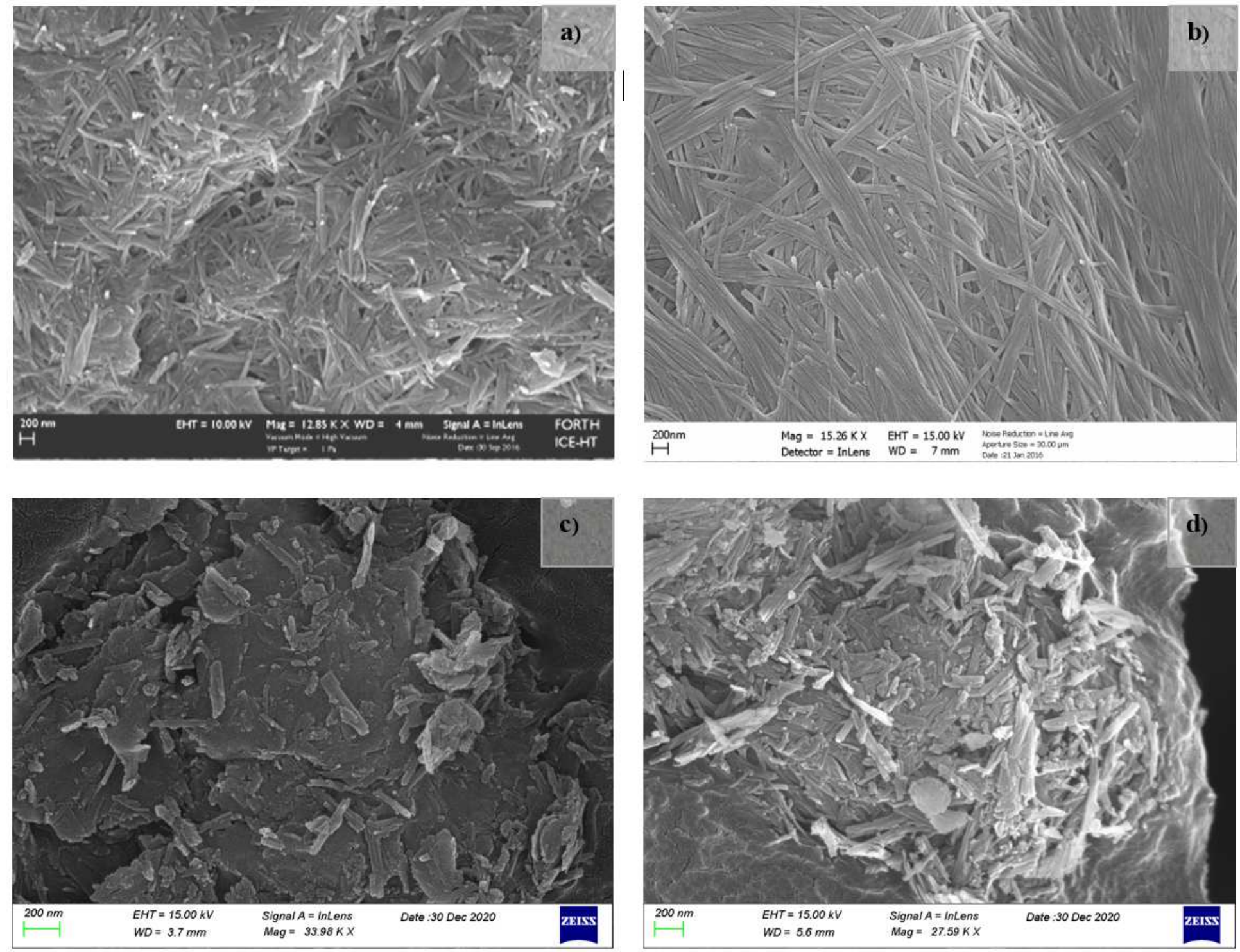

Figure 2

Scanning Electron Microscopy (SEM) images of a) Pal b) Sep c) T-Pal and d) T-Sep at $200 \mathrm{~nm}$. 


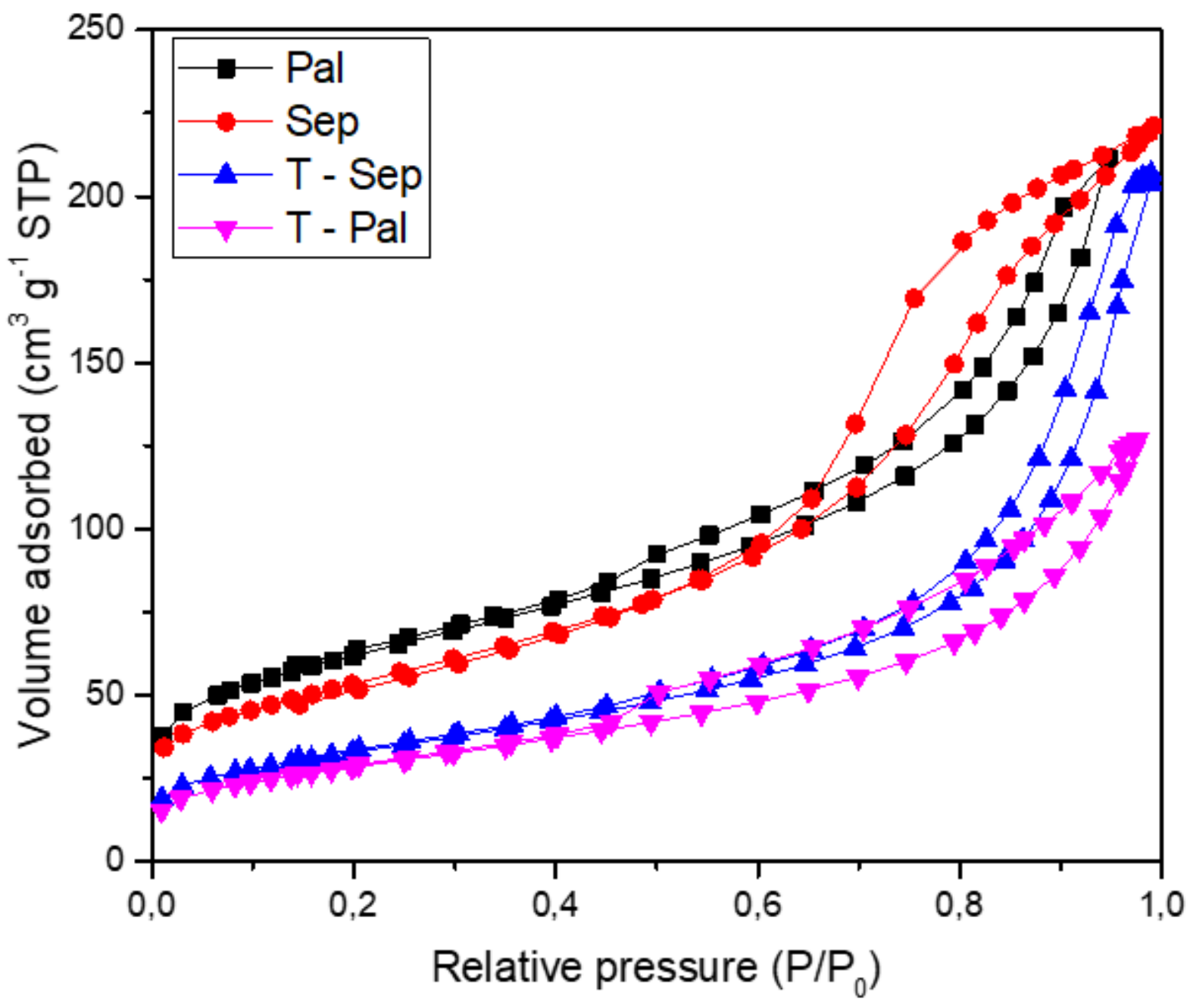

Figure 3

N2 sorption - desorption isotherms plot from BET analysis for Pal, Sep, T-Pal and T-Sep. 

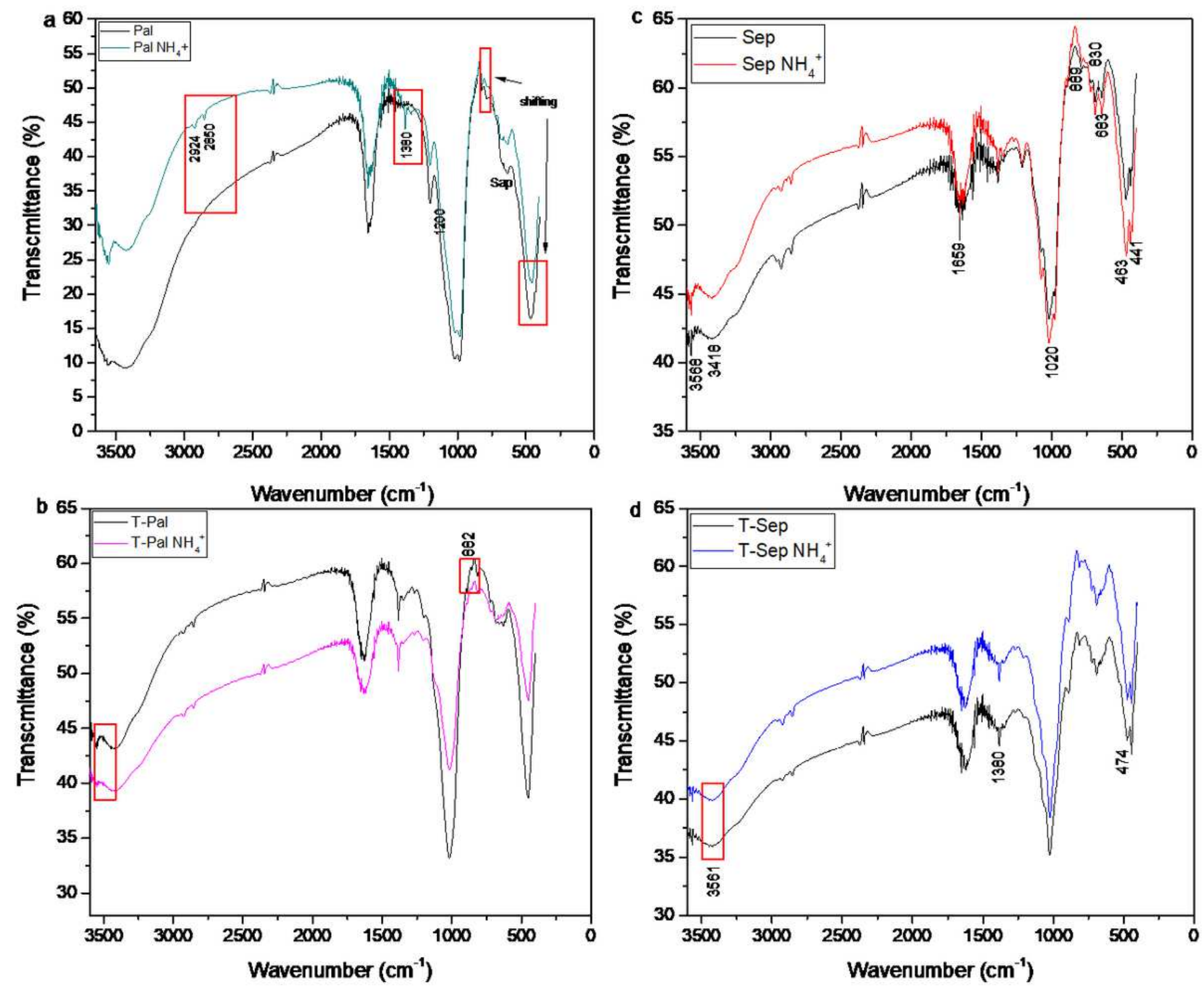

Figure 4

FT-IR spectra before and after NH4+-N adsorption of a) Pal b) T-Pal c) Sep and d) T-Sep. 


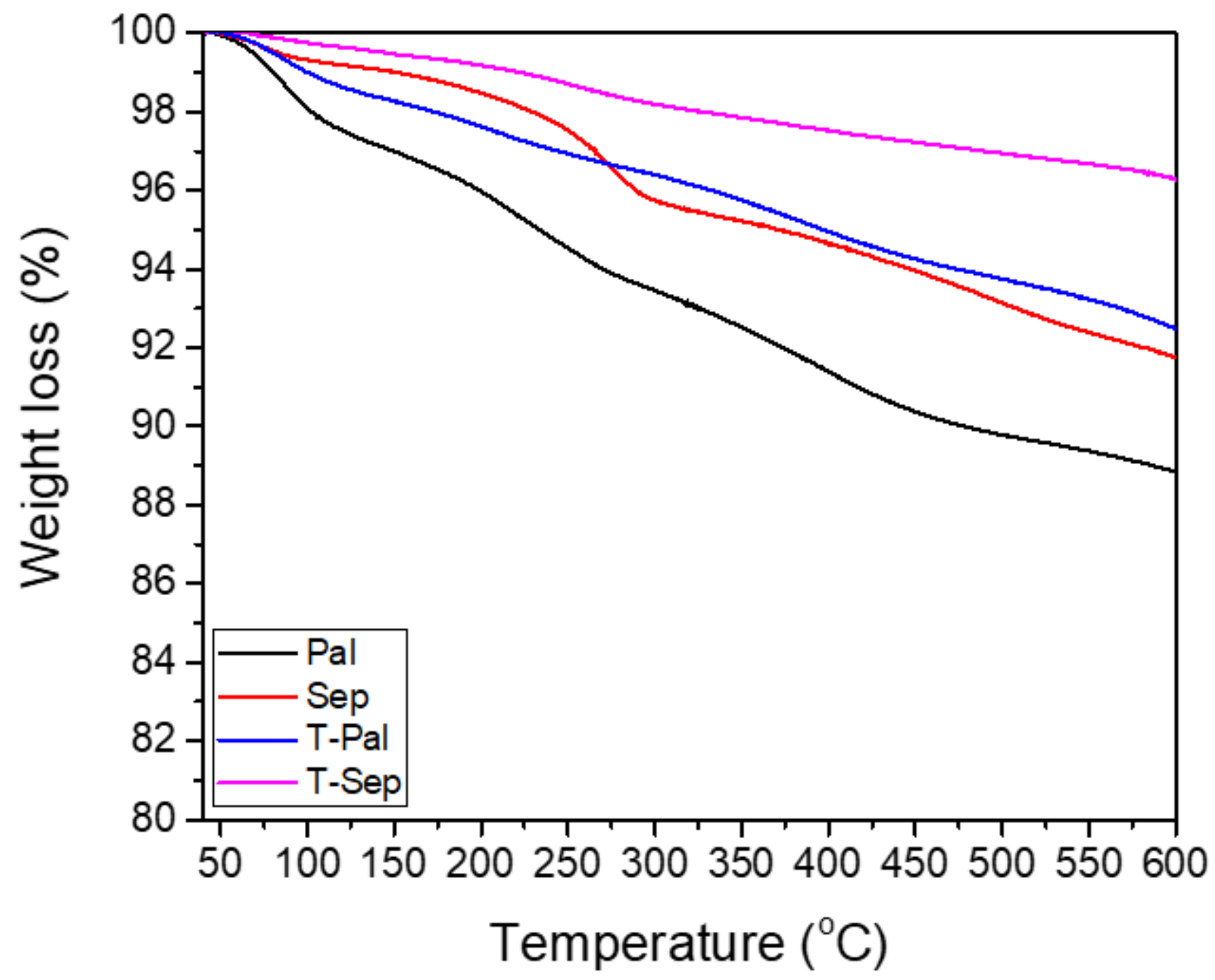

Figure 5

TGA curves of Pal, Sep, T-Pal and T-Sep. 


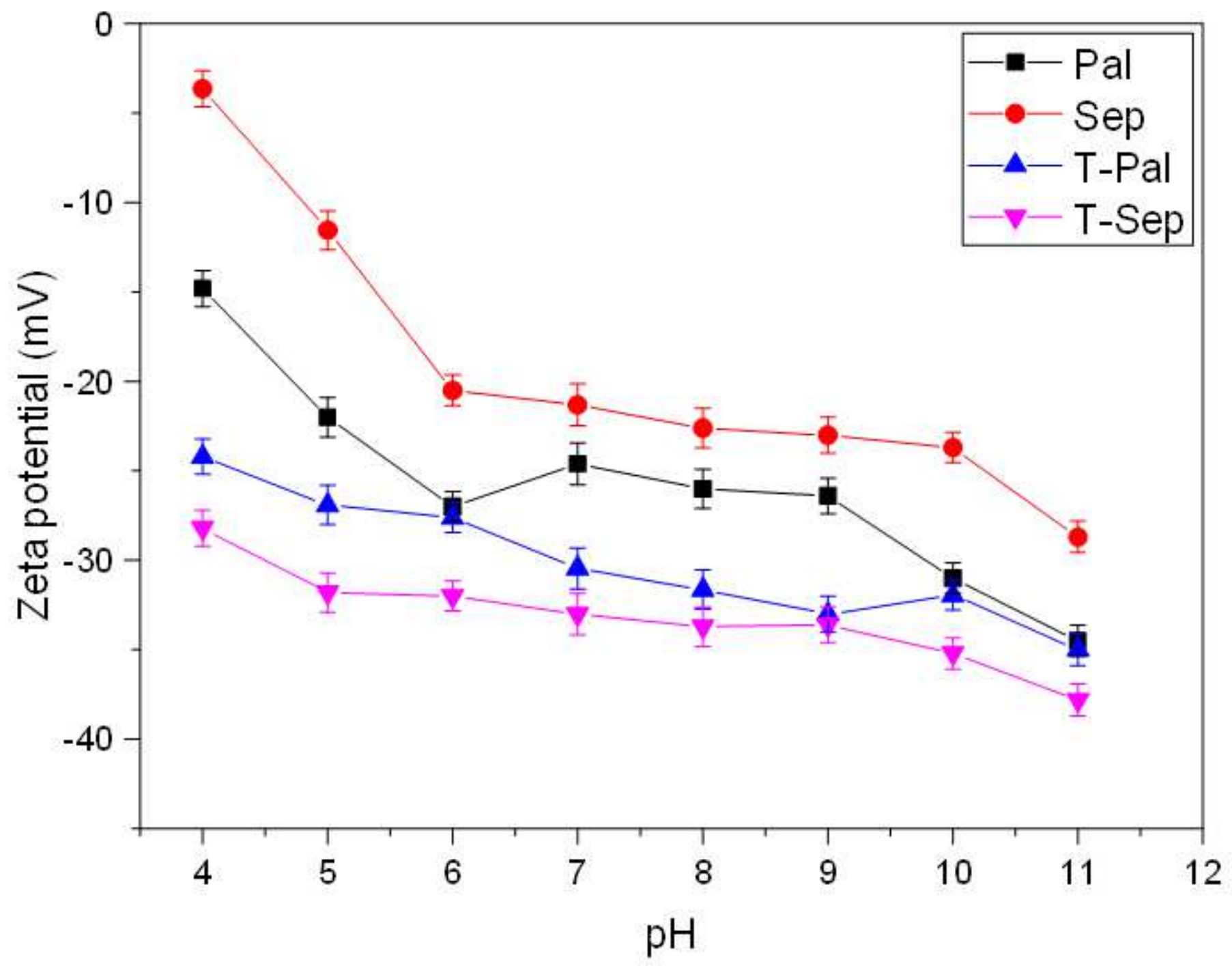

Figure 6

The zeta potential of Pal, Sep, T-Pal and T-Sep at pH range 4-11. 

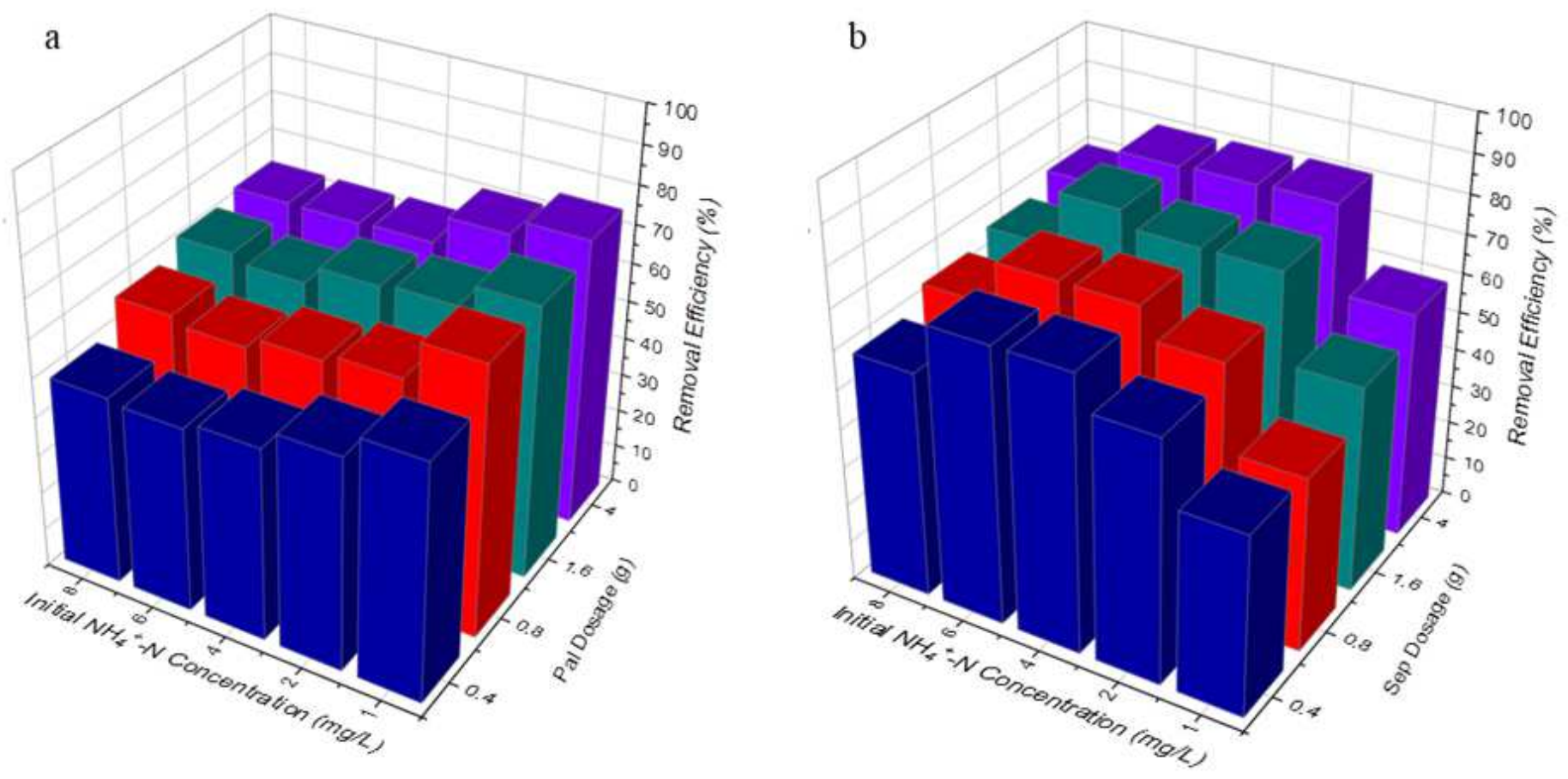

Figure 7

Maximum NH4+-N Removal Efficiency (\%) with $0.4,0.8,1.6$ and $4 \mathrm{~g}$ a)Pal and b)Sep for NH4+-N initial concentration 1, 2, 4, 6 and $8 \mathrm{mg} / \mathrm{L}$. The removal efficiency (\%) is the mean value from duplicate experiments.
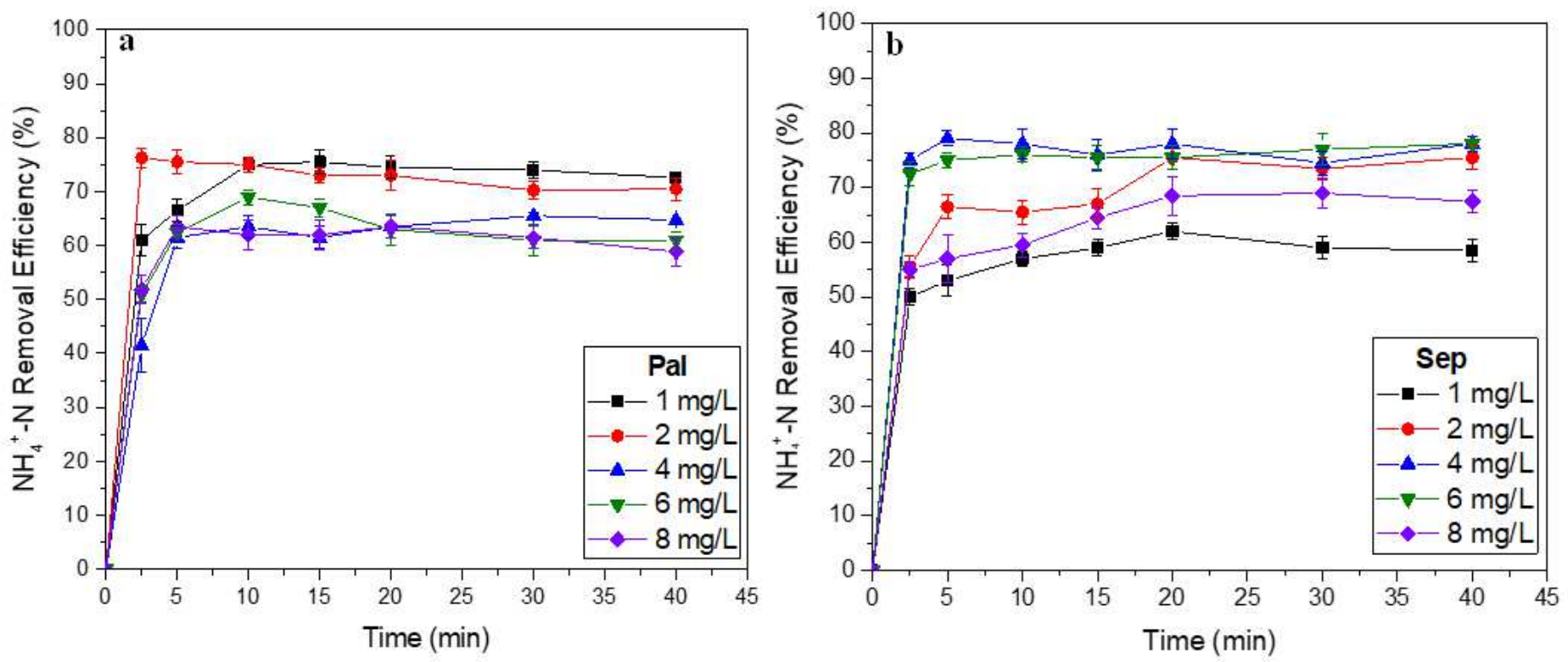

Figure 8

The effect of initial concentration on NH4+-N removal by $4 \mathrm{~g}$ a) Pal and b) Sep. 

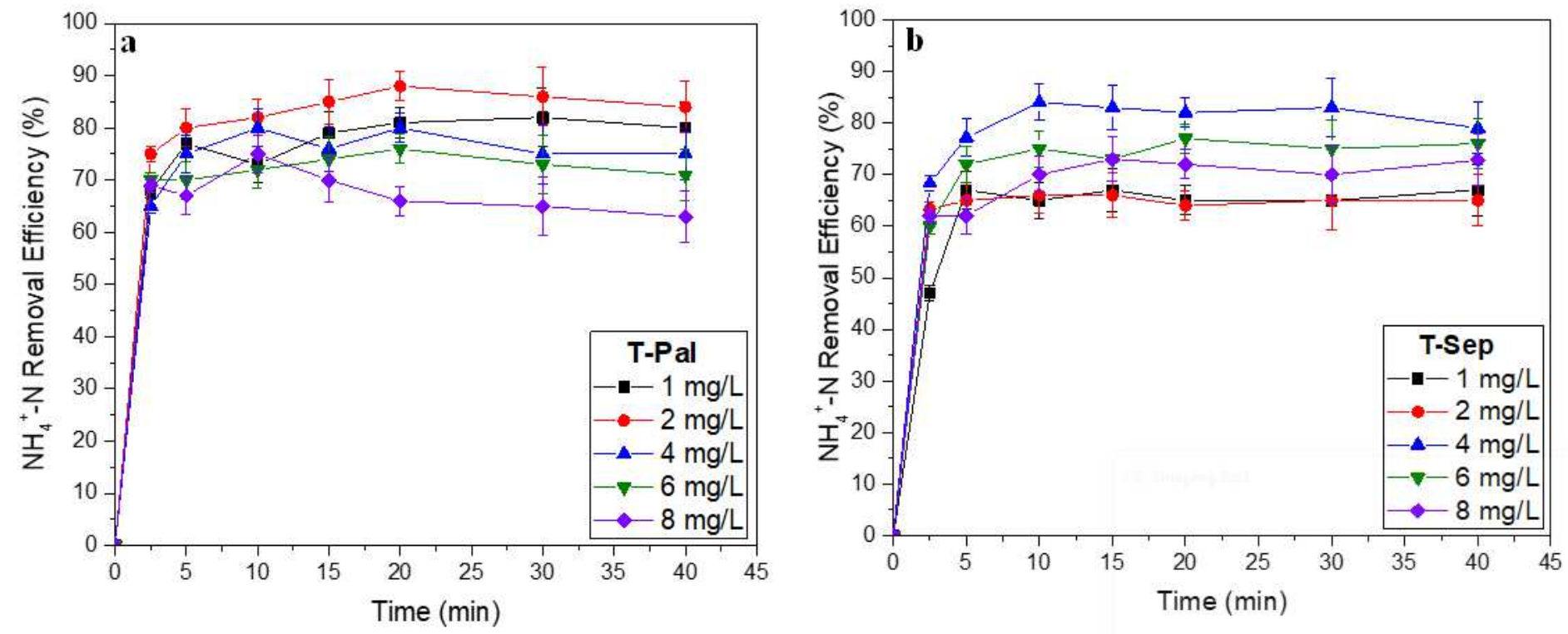

Figure 9

The effect of initial concentration on NH4+-N removal by $4 \mathrm{~g}$ a) T- Pal and b) T-Sep. 


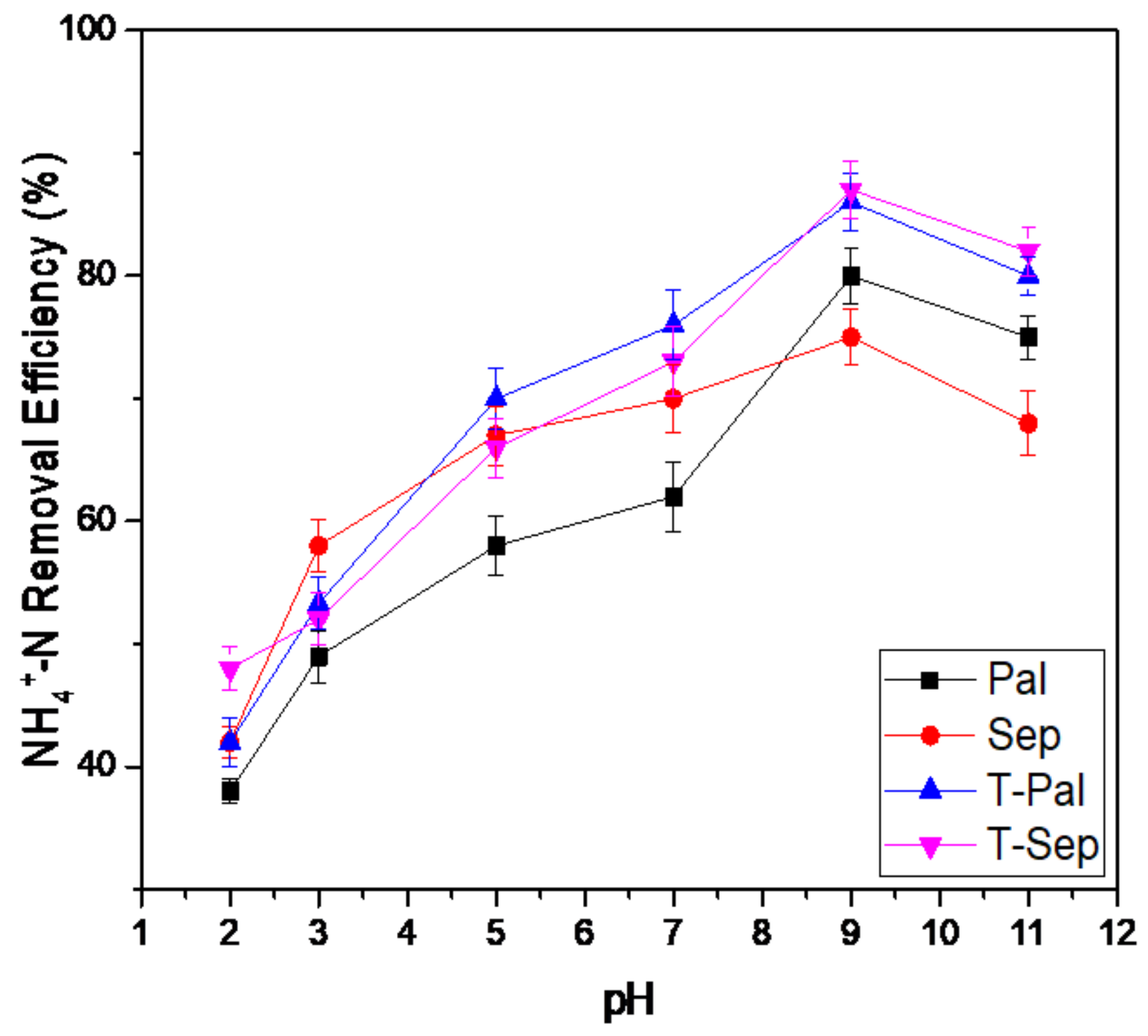

Figure 10

The effect of pH on NH4+-N removal by $4 \mathrm{~g} \mathrm{Pal}$, Sep, T- Pal and T-Sep. (4 mg NH4+-N /L, V= $200 \mathrm{ml}, 20$ $\min )$ 


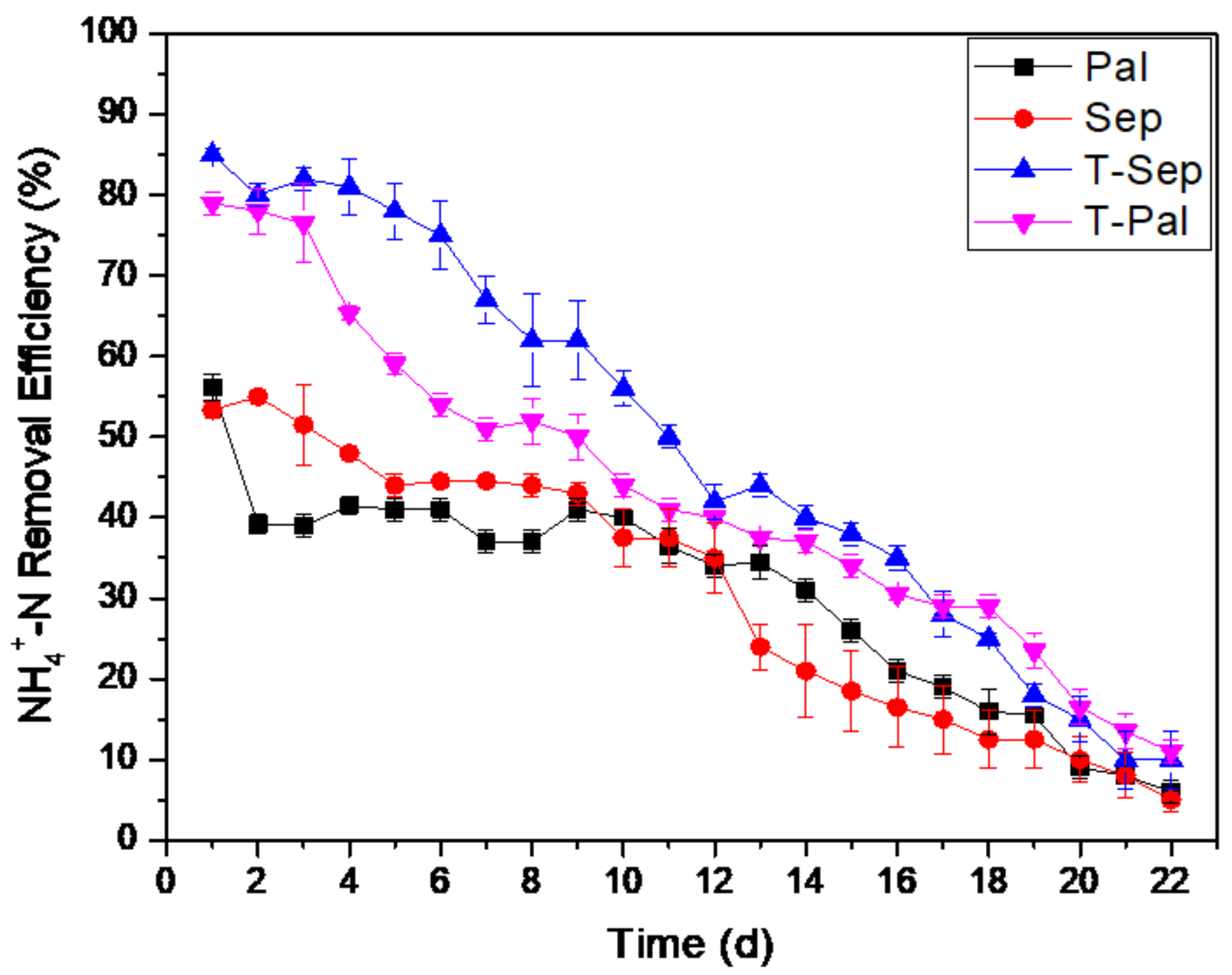

Figure 11

Saturation test of $4 \mathrm{~g} \mathrm{Pal}$, Sep, T-Pal and T-Sep in NH4+-N solution. (4 mg NH4+-N /L, V= $200 \mathrm{ml}, \mathrm{pH}=5.5$ ) 


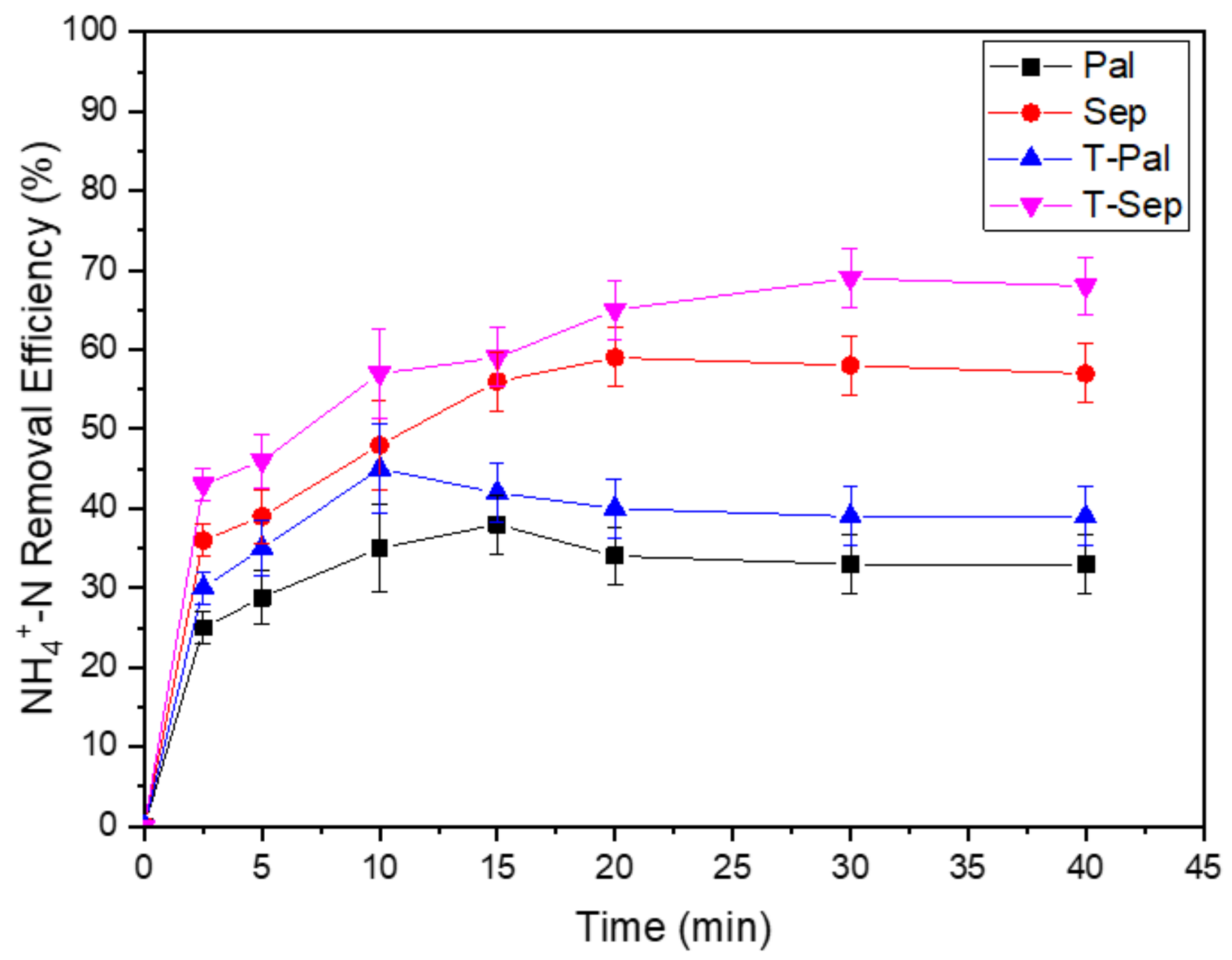

Figure 12

Removal efficiency (\%) of $4 \mathrm{~g} \mathrm{Pal}$, Sep, T-Pal and T-Sep in real water sample contaminated with $4 \mathrm{mg} / \mathrm{L}$ $\mathrm{NH} 4+-\mathrm{N}$.

\section{Supplementary Files}

This is a list of supplementary files associated with this preprint. Click to download.

- Graphicalabstract.png 